\title{
PRIVILEGED INFORMERS: THE ATTORNEY SUBPOENA PROBLEM AND A PROPOSAL FOR REFORM*
}

\author{
Max D. Sternt \\ David HoFFMAN $\dagger \dagger$
}

Table of Contents

I. Introduction . . . . . . . . . . . . . . . . 1785

A. The Attorney Subpoena: $A$ "New Investigative Tool" .............................. 1786

B. The Problem with Attorney Subpoenas....... 1789

II. Gurrent Treatment of Atrorney Subpoenas... 1795

A. The Judicial Response . . . . . . . . . . . . . . 1795

1. Attorney-Glient Privilege and Work-Product Doctrine ...................... 1796

a. Client Identity and Fee Information ... 1798

b. Crime/Fraud Exception ........... 1800

c. Work-Product Doctrine ............. 1801

* Copyright 1988 by Max D. Stern and David A. Hoffman. The authors wish to express their thanks to Akhil Amar, Jonathan Backman, Carol Donovan, Monroe Freedman, and David Leeder for their helpful suggestions and comments on an earlier draft of this Article; to Rachel Brill, Bernard Harcourt, and Dina Moakley for outstanding research assistance; to Jeanne Baker, Norman Lefstein, and other members of the National Network for the Right to Counsel Board for ideas culled from their legislative drafting efforts; and to the editors of the Law Review for their patient editorial work. The authors participated as counsel in a case involving the attorneysubpoena issue that is discussed in this Article. See United States v. Klubock, 639 F. Supp. 117 (D. Mass. 1986), aff'd by an equally divided court, 832 F.2d 664 (1st Cir. 1987) (en banc). The district court opinion had been first affirmed by a First Circuit panel. See United States v. Klubock, 832 F.2d 649 (1st Gir. 1987), vacated, United States v. Klubock, No. 86-1413 (1st Cir. May 1, 1987) (order granting rehearing en banc, which withdrew the panel's opinion and vacated its judgment); see also United States v. Klubock, 832 F.2d 664, 665 (en banc) (per curiam) (noting that the panel decision had been vacated as is customary when the court grants a petition for rehearing en banc). However, the half of the en banc court that voted to affirm the district court opinion also adopted the vacated majority panel opinion. See Klubock, 832 F.2d at 665 (Torruella, C.J.). We wish to thank our colleagues in the Klubock case for ideas that developed in the course of that litigation: Peter Agnes, Jeanne Baker, Paul Diamond, Matthew Feinberg, Benjamin Fierro, Patricia Garin, Stephen Goldblatt, Michael Greco, Richard Renehan, and Edward Smith.

† A.B. 1966, Dartmouth College; LL.B. 1969, University of Pennsylvania. Partner, Stern \& Shapiro, Boston, Massachusetts; Lecturer in Law, Harvard Law School. † A.B. 1970, Princeton University; M.A. 1974, Cornell University; J.D. 1984, Harvard University. Associate, Hill \& Barlow, Boston, Massachusetts. 
d. Conclusion ................... 1804

2. Constitutional Protection ............... 1804

3. Supervisory Power . . . . . . . . . . . . . 1807

a. Doe and Harvey ................ 1809

b. United States v. Klubock ........... 1811

c. Other Applications of Supervisory Power 1813

B. Ethical Rules ........................ 1815

C. United States Dep't of Justice Guidelines....... 1817

D. The Bar Response .................. 1820

III. Proposals for the Regulation of Attorney SubPOENAS . . . . . . . . . . . . . . . . . . . . . . . . . . 1824

A. The Policies at Stake ................ 1824

1. The Role of the Attorney and the AttorneyClient Privilege ................. 1825

2. The Role of the Grand Jury ......... 1827

B. A Balancing Act: Four Proposals for Regulation of Attorney Subpoenas ... . . . . . . . . . . . . . . 1829

1. Judicial Review for Necessity........... 1831

2. Pre-Issuance Judicial Review . . . . . . . . . 1834

3. A "Non-Incrimination" Privilege ......... 1835

a. Client Identity, Fees, and Expenses.... 1838

b. Work Product ................. 1841

c. Exceptions ................. 1842

(i) "Use Immunity" . . . . . . . . . 1842

(ii) Pre-existing Materials ......... 1842

(iii) Criminal Conduct in the Representation ................. 1843

4. A "Current Representation" Privilege ..... 1843

IV. Conclusion . . . . . . . . . . . . . . . . . . . . 1845

APPENDICES . . . . . . . . . . . . . . . . . . 1848

Appendix A: . . . . . . . . . . . . . . 1848

U.S. Department of Justice: Attorney-Subpoena Guidelines .................. 1848

Appendix B: . . . . . . . . . . . . . 1850

National Network for the Right of Counsel:

Attorney-Subpoena Proposal . . . . . . . . . . 1850

Appendix C: . . . . . . . . . . . . . . . 1852

American Bar Association Resolution ...... 1852

Appendix D: . . . . . . . . . . . . . . . . . . . 1853

American Bar Association Resolution ..... 1853 


\section{INTRODUCTION}

Case No. 1: Business partners A, B, and G consult a lawyer when $A$ is subpoenaed to a federal grand jury. The three fear that the investigation could come to focus on them all. After the lawyer appears with $A$, the Government subpoenas the lawyer to discover who else consulted her. ${ }^{1}$

Case No. 2: To show the financial resources of a defendant in a prosecution for an alleged tax offense, the government subpoenas the defense lawyer to testify concerning the legal fee paid. ${ }^{2}$

Case No. 3: A defendant's affidavit in support of a motion to suppress is contradicted by a government witness. While the case is still pending, the defense lawyer is subpoenaed to a grand jury investigating her client's alleged perjury to testify about all of her conversations with her client regarding the affidavit. ${ }^{3}$

Case No. 4: The lawyer for the target of a grand jury investigation monitors the witnesses appearing before the grand jury and informs her client about what she learns. After indicting the client for the substantive offense, but before trial, the grand jury opens an investigation into whether the client obstructed justice and subpoenas the lawyer to uncover what she told her client about the investigation. ${ }^{4}$

In none of these cases did the lawyer commit any wrongdoing. Moreover, in each, the lawyer had a well-recognized ethical duty to preserve the confidentiality of the information sought by the govern-

2 See, e.g., United States v. Castellano, 610 F. Supp. 1151, 1159 (S.D.N.Y. 1985) (government sought to call attorney representing multiple clients during grand jury investigation as a witness at trial to prove existence of criminal enterprise); see also infra notes 56-65 and accompanying text (discussing client identity and fee information); infra note 19 (discussing Department of Justice attorney subpoena statistics).

2 See, e.g., In re Grand Jury Subpoena Duces Tecum (Shargel), 742 F.2d 61, 6364 (2d Cir. 1984) (granting government's request for disclosure by attorney of client identity and fee information so that government could use the information "as evidence of unexplained wealth which may have been derived from criminal activity . . . and as evidence of the violation of the tax laws").

${ }^{3}$ See United States v. Morales-Martinez, 672 F. Supp. 762, 764 (D. Vt. 1987). After the lawyer submitted what the government later alleged was a fraudulent passport on behalf of the client at a bail hearing, see $i d$. at 763 , the attorney was subpoenaed to the grand jury to testify about "the content of your discussion with your client before you proffered the passport to the magistrate." Id. at 764. The court held that the information was covered by the crime/fraud exception to the attorney-client privilege. See id. at 765-66; see also infra notes 54-55 \& 66-75 and accompanying text (discussing crime/fraud exception).

- See In re Grand Jury Testimony of Attorney X, 621 F. Supp. 590, 592-94 (E.D.N.Y. 1985) (holding that information relayed by attorney merely as "conduit" to client regarding grand jury investigation was not covered by attorney-client privilege, not covered by work-product privilege because they were not a result of an attorney's thought processes or mental impressions and because the government made requisite showing of need). 
ment. ${ }^{5}$ According to theories advanced by government lawyers in recent years, however, the client information in these cases is not privileged. Indeed, under current Justice Department policy, the lawyer may be subpoenaed, compelled to testify, and, in all probability, forced to withdraw from the case. ${ }^{6}$

\section{A. The Attorney Subpoena": A "New Investigative Tool"}

Until very recently, the notion of subpoenaing a lawyer to testify about a client, in the very matter in which the lawyer was serving as advocate, was almost unthinkable. By long-standing tradition, as well as ethical rule, a lawyer is discouraged or prohibited from acting as advocate and witness in the same case, ${ }^{8}$ especially if the lawyer's testimony is harmful to the client. ${ }^{9}$ Thus, when the Supreme Court formulated the lawyer's work-product privilege in Hickman $v$. Taylor, ${ }^{10}$ the possibility that discovery of work product could lead to the lawyer's testimony was thought to be a powerful reason to deny discovery in the first place. ${ }^{11}$

- See Model Rules of Professional Conduct Rule 1.6(a) (1987); Model Code of Professional Responsibility DR 4-101(B) (1980).

${ }^{3}$ See, e.g., United States v. Diozzi, 807 F.2d 10, 12 (1st Cir. 1986) (government filed motion to disqualify attorneys because it intended to call them as witnesses); United States v. Castellano, 610 F. Supp. 1151, 1153 (S.D.N.Y. 1985) (government sought to disqualify attorney and offered as one ground its intention to call him as a witness):

7 As used in this Article, the term "attorney subpoena" means a grand jury or other subpoena issued to an attorney for the purpose of eliciting evidence about the attorney's client.

8 See Model Code of Professional Responsibility DR 5-101(B), DR 5-102 (1980); Model Rules of Professional. Conduct Rule 3.7 (1987).

- See Model Code of Professional Responsibility DR 5-102(B) (1980).

10329 U.S. 495 (1947).

11 See $i d$. at 513. In discussing the reasons against "forcing an attorney to repeat or write out all that witnesses have told him and to deliver the account to his adversary," id. at 512-13, Justice Murphy stated:

No legitimate purpose is served by such production. The practice forces the attorney to testify as to what he remembers or what he saw fit to write down regarding witnesses' remarks. Such testimony could not qualify as evidence; and to use it for impeachment or corroborative purposes would make the attorney much less an officer of the court and much more an ordinary witness. The standards of the profession would thereby suffer.

Id. at 513. In his concurrence, Justice Jackson stated:

Every lawyer dislikes to take the witness stand and will do so only for grave reasons. This is partly because it is not his role; he is almost invariably a poor witness. But he steps out of professional character to do it. $\mathrm{He}$ regrets it; the profession discourages it. But the practice advocated here is one which would force him to be a witness, not as to what he has seen or done but as to other witnesses' stories, and not because he wants to do so but in self defense. 
In the criminal context, prior to 1980 , federal prosecutors generally believed that lawyers were not potential sources of information in criminal investigations. ${ }^{12}$ Subpoenas to lawyers were rare and the government was generally not successful in enforcing them. ${ }^{13}$ However, Justice Department officials in the Reagan administration reexamined traditional assumptions about attorney subpoenas as they formulated aggressive approaches to criminal investigation. They concluded that prosecutors had wrongly assumed this investigative technique to be unavailable. $^{14}$ The Department then took the position that the attorney subpoena was a "new investigative tool" that could be used if nonprivileged information in the hands of the attorney could be identified. ${ }^{16}$ This change in prosecutorial doctrine coincided with developments in substantive criminal liability that made it more feasible to characterize the provision of legal services as relevant to proof of a criminal enterprise. ${ }^{16}$

The result has been an explosion of subpoenas to lawyers, based upon aggressive and imaginative exploitation of arguable exceptions to

Id. at 517 (Jackson, J., concurring); see also Special Project, The Work Product Doctrine, 68 CoRnell L. REv. 760, 787 (1983) (Hickman advanced the idea that "protection of work product immunity is necessary to prevent attorneys from testifying against their clients.").

${ }^{12}$ W. Landers, Remarks at the Conference on Defending the Right to Counsel, held at New York University Law School (Nov. 15, 1986) (tape recording on file with the University of Pennsylvania Law Review).

13 See, e.g., United States v. Hodge \& Zweig, 548 F.2d 1347, 1355 (9th Cir. 1977) (upholding subpoena, but stating broad grounds for disallowance); In re Grand Jury Proceedings (Jones), 517 F.2d 666, 674 (5th Gir. 1975) (invalidating subpoena compelling attorneys to testify before grand jury as to fee information); Tillotson v. Boughner, 350 F.2d 663, 666 (7th Cir. 1965) (identity of client within attorney-client privilege); Baird v. Koerner, 279 F.2d 623, 630-32 (9th Cir. 1960) (disallowing IRS subpoena for client identity); $c f$. Rice v. Baron, 456 F. Supp. 1361, 1370 (S.D.N.Y. 1978) (advocatewitness rule "was not designed to permit a lawyer to call opposing counsel as a witness and thereby disqualify him as counsel" "(citations omitted)).

14 See W. Landers, supra note 12.

is See id.

16 Prior to the advent of the RICO, 18 U.S.C. $\$ \S 1961-68$ (1982 \& Supp. IV 1986), and Continuing Criminal Enterprise, 21 U.S.C. § 848 (1982 \& Supp. IV 1986 \& West Supp. 1987), statutes, a federal conspiracy was considered to be concluded once its original singular objective had "ended in success or failure," Krulewitch v. United States, 336 U.S. 440, 443 (1949). This rule generally precluded evidence concerning the legal defense from being admitted in the trial of the underlying conspiracy. However, under modern theories of "enterprise" liability, which permit proof of conspiracies with multiple conspiratorial objectives, prosecutors have been able to characterize provision of legal services in particular cases as a "fringe benefit" of the criminal enterprise, and thus relevant to proof of its existence. See e.g. In re Grand Jury Proceedings (Pavlick), 680 F.2d 1026, 1029 (5th Cir. 1982) (agreement to provide legal services stands on same legal footing as provision of "any other portion of the conspiracy's fruits"). 
the attorney-client and work-product privileges. ${ }^{17}$ One national survey of over 1000 practicing criminal defense lawyers found that attorneys were subpoenaed infrequently prior to 1980 , but documented a "dramatic increase" in the practice since then, with an "enormous" jump between 1983 and mid-1985..$^{18}$ More recent statistics released by the Department of Justice indicate a steady increase in the number of attorney subpoenas approved by the Griminal Division. ${ }^{18}$ The record in

17 See Fried, Too High a Price for Truth: The Exception to the Attorney-Client Privilege for Contemplated Crimes and Frauds, 64 N.C.L. REv. 443, 471-76 (1986) (expansion of federal criminal jurisdiction has encouraged federal prosecutors to make greater use of the crime-fraud exception to the attorney-client privilege); Glanzer \& Taskier, Attorneys Before the Grand Jury: Assertion of the Attorney-Client Privilege to Protect a Client's Identity, 75 J. CRIM. L. \& CRIMINOLOGY 1070, 1070-71 (1984) ("It is apparent from a number of recent investigations that attorney testimony before the grand jury has become an increasingly favored tool of prosecutors in discovering information or proof necessary to build a case against the target of an investigation."); J. Backman, The Lawyer-Client Subpoena: A Proposal for Reform 8 (Apr. 30, 1987) (unpublished manuscript on file with the University of Pennsylvania Law Review) ("OO]ver the past decade, the government has discovered that the lawyer-client subpoena is a powerful weapon, capable of severely weakening its only barrier to unbridled investigation and prosecution.").

18 See Genego, Risky Business: The Hazards of Being a Criminal Defense Lawyer, GRim. Just., Spring 1986, at 2, 40.

18 In May 1986, the Department released a statistical analysis of grand jury subpoenas to lawyers during the first six months in which the Department's attorney subpoena guidelines were in effect, July 18, 1985 through February 18, 1986. See Letter from William Landers, Special Counsel to the Assistant Attorney General, Criminal Division, to Laurie Robinson, Director, ABA Section of Criminal Justice [hereinafter Letter of May 19, 1986]. In December, 1986 the Department released a statistical analysis for the period March 1 through July 31, 1986 for both grand jury and trial subpoenas. See Letter from William Landers, Deputy Associate Attorney General, to Laurie Robinson [hereinafter Letter of December 12, 1986].

According to these statistics, in the course of the 12 months surveyed, the Department of Justice approved more than 400 requests to issue grand jury subpoenas to attorneys. See Letter of Dec. 12, 1986, supra; Letter of May 19, 1986, supra.. In the first six month period there were 169 such subpoenas. Of these, 45 were for information concerning a client who was currently represented by the attorney, and 26 of these were issued to attorneys who were representing the client in connection with the same grand jury investigation. See Letter of May 19, 1986, supra.

In the second period, the Department reported 242 grand jury subpoenas and 45 trial subpoenas. Of the 49 grand jury subpoenas issued to attorneys who represented clients in criminal matters, more than one-third were issued to attorneys who were representing clients in investigations in which the subpoenas were issued. See id. Two of the trial subpoenas were to attorneys who then represented the client, or who had previously represented the client in the same matter but had withdrawn or had been disqualified by court order. See id. at Table 2 .

The December 1986 analysis also provided a breakdown of categories of information sought, which included:

a) Documents-corporate/financial/real estate documents.

b) Fee information includ[ing] subpoenas for documents and/or for testimony regarding fees paid to attorneys, including amount, source, and identity of fee payors.

c) Testimony sought from an attorney as a "fact witness," [including] 
the only case to focus on the rate of such subpoenas suggests a much heavier actual use of attorney subpoenas in the field than is indicated in the Justice Department statistics: in that district, the government admitted to issuing from 50 to 100 such subpoenas per year. ${ }^{20}$ The Justice Department's statistics show, moreover, that attorney subpoenas have not been directed to criminal defense lawyers alone. On the contrary, the "vast majority" have been directed to civil attorneys. ${ }^{21}$

\section{B. The Problem With Attorney Subpoenas}

Serving a subpoena upon defense counsel in a criminal case in order to obtain information about the attorney's client is extremely problematic: disruptive at best, and fatal to the client's representation at worst. As one court put it, "[t]he serving of a subpoena under such circumstances will immediately drive a chilling wedge between the attorney/witness and his client."22

The power to subpoena one's adversary usually carries with it the

situations in which an attorney was a witness to some event or transaction in a setting in which no privilege applied; for example, where an attorney was a witness to a business transaction involving the client and a third party. Additionally, where the attorney currently represented the client on a criminal matter, either grand jury or trial, the testimony concerned observation of some fact not related to the current representation.

d) [T] estimony concerning "advice or assistance" ... [where] the information was not privileged because of the crime/fraud exception or because the client had raised an advise [sic] of counsel defense; for example where the attorney had issued a letter opinion with regard to an investment scheme which was now the subject of a fraud investigation ... . lor for example,] testimony [was sought] concerning advice or assistance rendered by the attorney to the client regarding an investment scheme or treatment of an item on a tax return where the investment scheme or tax return is the subject of the criminal trial and the client is claiming a "reliance on counsel" defense.

Id. Attachment to Tables.

${ }_{20}$ See United States v. Klubock, 832 F.2d 649, 658 (1st Cir. 1987), vacated, United States v. Klubock, No. 86-1413 (1st Cir. May 1, 1987) (order granting rehearing en banc, which withdrew the panel's opinion and vacated its judgment); see also United States v. Klubock, 832 F.2d 664, 665 (en banc) (Torruella, G.J.) (stating that the three judges voting to affirm the district court also "abide by the majority panel opinion"); supra note * (explaining that the half of the en banc court that voted to affirm the district court's decision also adopted the vacated majority panel opinion). The Court of Appeals noted that, given the district's statistics for criminal business, the government's admission raised the possibility of attorney subpoenas in from $10.7 \%$ to $32.6 \%$ of criminal cases in the district. See Klubock, 832 F.2d at 658; see also infra text accompanying notes $133-43$ (discussing Klubock).

${ }^{21}$ See Rudolf \& Maher, A Subpoena a Day Keeps the Clients Away, CrIM. Just., Fall 1986, at 4, 5. Although this Article focuses on attorney subpoenas issued by prosecutors and grand juries, much of our discussion relates equally to subpoenas used in civil titigation.

${ }_{22}$ Klubock, 832 F.2d at 653 (majority opinion of panel). 
power to control who the adversary will be. ${ }^{23}$ If the lawyer has been subpoenaed to the trial, or will be as a result of a grand jury subpoena, the lawyer will usually have to withdraw, since a lawyer is generally prohibited from acting as an advocate and witness in the same trial. ${ }^{24}$

${ }^{23}$ See id. at 654 (service of subpoena "potentially gives [prosecutor] control over who shall be his attorney/adversary").

24 See id. (service of subpoena will possibly cause defense attorney to resign as counsel for his client since Canons of Ethics prohibit the attorney from being witness and attorney in the same case); United States v. Diozzi, 807 F.2d 10, 12-13 (1st Cir. 1986) ("[A]ttorneys [can]not serve the dual roles of defense counsel and sworn government witnesses in the same trial.”). Compare Kroungold v. Triester, 521 F.2d 763, 766 (3d Cir. 1975) (when attorney is called as witness and nothing in her testimony will be prejudicial to her client, attorney is not disqualified) and Ross v. Great Atl. \& Pac. Tea Co., 447 F. Supp. 406, 408 (S.D.N.Y. 1978) ("Under [D.R. 5-102(B)], the party seeking disqualification must show that the testimony to be elicited from his adversary will be prejudicial to the latter's client.") and MOdel Code of Professional ReSPONSIBILITY DR 5-102(B) (1980).

The Model Rules of Professional Conduct also prohibit the lawyer from acting as both advocate and witness whenever "the lawyer is likely to be a necessary witness," Model. Rules of Professional Conduct Rule 3.7(a) (1987), thus, apparently, forbids representation when the lawyer is subpoenaed whether or not the testimony is prejudicial to the client. The rule, however, is subject to certain exceptions including when "disqualification of the lawyer would work substantial hardship on the client." Id. Rule 3.7(a)(3).

Whatever theoretical leeway is granted by the advocate/witness rules when the attorney is an unwilling witness, however, is severely limited by the unlikelihood that the attorney can act as witness and simultaneously fulfill her duty to provide effective representation. See State v. Thomas, 53 Or. App. 375, 380, 631 P.2d 1387, 1390 (1981)

[A] defendant's right to effective representation may be impaired while his counsel is on the witness stand for the prosecution, because: (1) it is impossible for the defendant to consult with his attorney; (2) the defendant cannot call attention to any inaccuracy in the attorney's testimony or suggest proper questions for cross-examination; (3) it is difficult, to say the least, for the lawyer, as a witness, to determine what objections should be made to questions asked him; (4) it is difficult for the lawyer to determine what questions to ask himself on cross-examination, and if he attempts to cross-examine himself the proceedings may take on a ludicrous appearance; and (5) it is difficult for the lawyer to answer questions so as not to antagonize the jury and still maintain a favorable impression.

See also Kaeser v. State, 96 Nev. 955, 958, 620 P.2d 872, 873 (1980) ("The defendant is unable to consult with his counsel when counsel is on the stand as a witness. It is most difficult for counsel to protect the record and at the same time keep in mind what questions should be asked himself on cross-examination."); MODEL CODE OF PROFEsSIONAL RESPONSIBILITY EC 5-9 (1980) ("An advocate who becomes a witness is in the unseemly and ineffective position of arguing his own credibility.").

In any event, the duty of the witness to tell the objective truth is fundamentally different from the duty of the defense lawyer to present a one-sided impression to the fact-finder.

[A]bsent a voluntary plea of guilty, we . . . insist that [defense counsel] defend his client whether he is innocent or guilty. The State has the obligation to present the evidence. Defense counsel need present nothing, even if he knows what the truth is. He need not furnish any witnesses to the police, or reveal any confidences of his client, or furnish any other infor- 
Moreover, withdrawal should occur at the earliest possible time, so that new counsel will have time to prepare.

A grand jury subpoena is no less problematic than a trial subpoena even though the advocate/witness disqualification rules do not strictly apply. Turning the lawyer into a government witness usually places the lawyer in an immediate and very serious conflict of interest requiring withdrawal in and of itself. Obviously a conflict exists if the testimony is harmful to the client; and if the testimony is unhelpful to the prosecution or if the attorney is uncooperative, the lawyer may face recriminations from the government. In a real sense, the subpoena signifies official prosecutorial interest in the lawyer's own conduct and involvement with her client, the defendant or grand jury target. The attorney's actions in the case will now be subjected to grand jury scrutiny. The lawyer thus acquires what she earlier lacked: a personal interest in the matter. ${ }^{25}$

This situation creates considerable opportunities for abuse. ${ }^{28}$ The power to hale an attorney into the grand jury room to investigate the

mation to help the prosecution's case. If he can confuse a witness, even a truthful one, or make him appear at a disadvantage, unsure or indecisive, that will be his normal course. Our interest in not convicting the innocent permits counsel to put the State to its proof, to put the State's case in the worst possible light, regardless of what he thinks or knows to be the truth. Undoubtedly there are some limits which defense counsel must observe but more often than not, defense counsel will cross-examine a prosecution witness, and impeach him if he can, even if he thinks the witness is telling the truth, just as he will attempt to destroy a witness who he thinks is lying. In this respect, as part of our modified adversary system and as part of the duty imposed on the most honorable defense counsel, we countenance or require conduct which in many instances has little, if any, relation to the search for truth.

U.S. v. Wade, 388 U.S. 218, 257-58 (1967) (White, J., dissenting in part and concurring in part) (emphasis added) (citations omitted).

${ }^{2 s}$ In Klubock, the court stated:

More subtle, but perhaps more important in terms of the ethical setting ...., is the immediate conflict of interests created between the attorney/ witness and his client by the serving of a subpoena . . . As a witness, the attorney/witness has separate legal and practical interests apart from those of his client. These interests may or may not coincide with those of the attorney/witness and his client. The mere possibility of such a conflict is sufficient to create a problem.

United States v. Klubock, 832 F.2d 649, 653 (1st Cir. 1987), vacated, United States v. Klubock, No. 86-1413 (1st Cir. May 1, 1987) (order granting rehearing en banc, which withdrew the panel's opinion and vacated its judgment); see also United States v. Klubock, 832 F.2d 664, 665 (en banc) (Torruella, C.J.) (stating that the three judges voting to affirm the district court's decision also "abide by the majority panel opinion"); supra note * (explaining that the half of the en banc court that voted to affirm the district court's decision also adopted the vacated majority panel opinion).

${ }_{28}$ "Last, but not necessarily least, is the potential for abuse that underlies the natural tendencies promoted by adversarial postures." Id. at 654 . 
attorney's representation of a client has an enormously intimidating effect. This threat may well be the very point for the unscrupulous prosecutor. "The unregulated power to subpoena attorneys also carries with it the potential for mischief inherent in any situation where one adversary can pummel his opponent without violating the rules."27 As noted in a recent American Bar Association report, "the prospect of striking at one's adversary by inflicting crippling blows on the adversary's attorney has proven increasingly irresistible to many lawyers."28

Moreover, if during the course of the representation, the attorney disappears into the grand jury room to answer questions about the client, the client may lose confidence in either the attorney's loyalty or her ability to protect the client and to maintain the client's confidences. ${ }^{29}$ Thus is eroded the relationship of trust and confidence that lies at the heart of the attorney-client relationship. ${ }^{30}$

Furthermore, the subpoena causes incalculable damage even if it is, or can be, quashed. The subpoena typically 'open[s] a 'second front' when the defendant has neither the time nor the resources to successfully fight on two battlegrounds." 31 Subpoena litigation is usually fast-

27 ABA, Report to the House of Delegates 6 (Feb., 1986) [hereinafter ABA Report I] (on file with the University of Pennsylvania Law Review); see In re Grand Jury Subpoena (Legal Services Center), 615 F. Supp. 958, 970 (D. Mass. 1985) (finding that subpoenas were unreasonable and oppressive); In re Grand Jury Matters (Hodes and Gordon), 593 F. Supp. 103, 107 (D.N.H.) (actions of U.S. Attorney held to be harassing), affd, 751 F.2d 13 (1st Cir. 1984).

${ }^{28}$ ABA Report I, supra note 27, at 2.

${ }^{29}$ See Alschuler, The Search for Truth Continued, the Privilege Retained: A Response to Judge Frankel, 54 U. Colo. L. Rev. 67, 73 (1982) (critical issue in assessing attorney-client privilege is "whether [the client] should "know as well as he is ever likely to know the future that giving the truth to his attorney will not hurt him." ") (citation omitted); Weiner, Federal Grand Jury Subpoenas to Attorneys: A Proposal for Reform, 23 AM. CRIM. L. REv. 95, 102-03 (1986) (discussing chilling effect on attorney-client relationship "[w]hether or not . . . [the subpoena] infringes on any recognized privilege"); see also infra note 224 (participants in federal grand jury proceedings are generally forbidden to disclose content of the proceedings).

30 "Most obvious is the fact that the client is uncertain at best, and suspicious at worst, that his legitimate trust in his attorney may be subject to betrayal." United States v. Klubock, 832 F.2d 649, 653 (1st Gir. 1987), vacated, United States v. Klubock, No. 86-1413 (1st Cir. May 1, 1987) (order granting rehearing en banc, which withdrew the panel's opinion and vacated its judgment); see United States v. Klubock, 832 F.2d 664, 665 (en banc) (Torruella, C.J.) (stating that the three judges voting to affirm the district court's decision also "abide by the majority panel opinion"); supra note * (explaining that the half of the en banc court that voted to affirm the district court's decision also adopted the vacated majority panel opinion); see also Morris v. Slappy, 461 U.S. 1, 21 \& $n .4$ (1983) (Brennan, J., concurring in the result) (noting need for "relationship characterized by trust and confidence" between attorney and client); ABA STANDARDS FOR CRIMINAL JUSTICE 4-3.1 (commentary) (2d ed. 1980) ("Nothing is more fundamental to the lawyer-client relationship than the establishment of trust and confidence.").

${ }^{31}$ Rudolf \& Maher, The Attorney Subpoena: You Are Hereby Commanded to 
track, intensive litigation that diverts counsel from the task of representation and often entails great expense. Indeed, the prudent attorney who receives a subpoena will retain her own lawyer to litigate that issue. As noted in the ABA Report:

The insidious nature of these indirect attacks is familiar to everyone who has inflicted, endured, or witnessed them: they divert attention from the merits of the case and generate complicated controversies about tangential issues; they sap the morale of the opposing advocate by focusing attention on his own conduct or by forcing him to defend his own interest; and they channel precious time, energy, and resources into diversionary skirmishes which inevitably weaken the opposition's taste and strength for the main fight. ${ }^{32}$

A correlative problem is posed by the risk of improper compromise or even betrayal of the client's rights under the pressure of the government's investigative power. The subpoena creates the risk that the subpoenaed attorney will disclose confidential information that can and should remain confidential. The nub of the problem is that attorneys do not always move to quash a subpoena even when they should. ${ }^{33}$ Indeed, an attorney may not even inform the client that the attorney has been subpoenaed. ${ }^{34}$

Reasons for not revealing the subpoena's existence to the client are

Betray Your Client, CRIM. Just., Spring 1986, at 14, 16.

${ }_{32}$ ABA Report I, supra note 27, at 2; see also Klubock, 832 F.2d at 653 (panel opinion):

Closely related to [the problem of conflict of interest] is the diversion of interests and resources brought about by the conversion of the attorney into a witness. The attorney now has a difficult "second front" to deal with, in which he must dedicate his own time and resources to looking after his own interests, while at the same time trying to protect those of his client. The strain on the attorney's time/resources, to say nothing of the disruption in his/her client's representation, goes far beyond a mere conflict of interest situation.

${ }^{33}$ This is hardly a speculative fear. In Klubock, 832 F.2d at 649, the Government admitted that "approximately 50-100 federal grand jury subpoenas per year have been served in Massachusetts upon attorneys for documents or testimony relating to a person represented by that attorney." (Record Appendix at 32). Yet, as the district judge noted, "given the numbers that you [the plaintiffs] cite as to the numbers of subpoenas that have been sent out and the number of motions to quash, relatively few [attorneys] appear to avail themselves of that opportunity and, thus, may be compromising their clients interests after all." (Record Appendix at 500). The government conceded in the district court that "most lawyers do not file a motion to quash." (Record Appendix at 500).

${ }^{34}$ See Note, The Attorney-Client Privilege After Attorney Disclosure, 78 MrcH. L. REv. 927, 927-29 (1980) (citing examples of attorney waiver of the attorney-client privilege without clients' consent and/or knowledge). 
readily apparent. The subpoena creates intense pressure by virtue of the fact that the attorney herself may have been threatened with, or fear, investigation. Even if she has no reason to fear such investigation, she may wish to avoid confrontation or publicity. She also may lack the money, energy, time, knowledge or ability to wage the aggressive and complicated battle that subpoena litigation frequently involves. As an order denying a motion to quash a subpoena may not be immediately reviewable, she may hesitate to resist the subpoena and thereby risk contempt, which she may well have to do if the client's appellate rights. are to be saved. ${ }^{35}$ At the same time, the subpoena constitutes an apparent legal command to produce evidence and thus offers a convenient, if insufficient, justification for capitulation. ${ }^{\text {s6 }}$ It presents an ideal opportunity for a prosecuting attorney to take advantage of a compromised lawyer in order to obtain client information. ${ }^{37}$

An unregulated policy of subpoenaing attorneys to give evidence about clients will, over the long term, inevitably have an inhibiting effect on legal practice. Clients will hesitate to consult lawyers unless absolutely necessary and will delay retaining counsel as long as possible. ${ }^{38}$ Persons who cannot on their own afford the crushing costs of modern-day criminal litigation will find it difficult or impossible to obtain financial assistance from friends, colleagues or supporters, who may fear exposure and embarrassment. Lawyers will insulate themselves from all but the bare minimum of knowledge that seems neces-

${ }^{35}$ In three circuits, the denial of a motion to quash is not immediately appealable. Therefore, in those circuits the attorney must be cited for contempt in order to obtain review of an adverse decision concerning her assertion of attorney-client privilege. See, e.g., In re Grand Jury Proceedings (Vargas), 723 F.2d 1461, 1464-66 (10th Cir. 1983) (client could not appeal denial of motion to quash subpoena directed at his attorney as it was reasonable to expect the attorney to risk a citation for contempt), enforced, 727 F.2d 941, 946 (10th Cir.), cert. denied, 469 U.S. 819 (1984); In re Sealed Case, 655 F.2d 1298, 1300-01 (D.C. Cir. 1981) (an order denying a motion to quash a subpoena duces tecum served on a corporation's outside counsel is not immediately reviewable); In re Oberkoetter, 612 F.2d 15, 16 (1st Cir. 1980) (discussing "well-settled rule that an attorney has no right to appeal from a district court order directing him to festify before a grand jury with respect to an attorney-client communication" as it is not a reviewable final decision).

${ }^{38}$ For an example in the civil context, see In re Beiny, 129 A.D.2d 126, 131-37, 517 N.Y.S.2d 474, 476-81 (1987), where petitioner's counsel obtained confidential attorney-client privileged documents of a trust by issuing a fraudulent deposition subpoena to the attorney-custodian of the records.

${ }^{37}$ See United States v. Ofshe, 817 F.2d 1508, 1510-11 (11th Cir.) (prosecutor induced defense lawyer under investigation for corruption to use a "body bug" to tape confidential conversations with client), cert. denied, 108 S. Ct. 451 (1987).

${ }_{38}$ See In re Grand Jury Subpoena Duces Tecum (Shargel) 742 F.2d 61, 63 (2d Cir. 1984) (stating that "we would be less than candid not to concede that the lack of a privilege against disclosure of the fact of an attorney-client relationship may discourage some persons from seeking legal advice at all"). 
sary for discrete legal services, thus increasing the risk of mistake and ineffective representation.

Such a policy will also demoralize the profession. It is not an overstatement to say that the government's new. attorney subpoena policy has caused widespread fear and anxiety in the criminal defense bar. ${ }^{39}$ It has also affected lawyers' decisions whether to take criminal cases, or certain types of criminal cases. ${ }^{40}$ "Although it is impossible to quantify accurately, it is logical to presume that the unrestricted use of [such] subpoenas . . . will tend to discourage attorneys from providing representation in controversial criminal cases."

\section{Gurrent Treatment of Atrorney Subpoenas}

As the use of attorney subpoenas has dramatically increased in recent years, the courts, the organized bar, and even the United States Department of Justice have adopted various methods of regulating the practice. This section focuses on the responses of each of these players to the attorney subpoena controversy.

\section{A. The Judicial Response}

A number of courts have noted with dismay the increasing use of attorney subpoenas and have responded accordingly. ${ }^{42}$ The judicial re-

${ }^{39}$ See In re Grand Jury Matters (Hodes and Gordon), 593 F. Supp. 103, 107 (D.N.H.) (attorney subpoenas have not merely a "chilling effect" but "an arctic effect with the non-salutary purpose of freezing criminal defense attorneys into inanimate ice floes, bereft of the succor of constitutional safeguards"), aff'd, 751 F.2d 13 (1st Cir. 1984).

40 See Genego, supra note 18, at 7 (fourteen percent of attorneys who reported having made changes in their practice as a result of government activities "had decided not to accept a specific criminal case or cases" because of Justice Department practices, including fee forfeiture and use of attorney subpoenas).

\$1 United States v. Klubock, 832 F.2d 649, 653-54 (1st Cir. 1987), vacated, United States v. Klubock, No. 86-1413 (1st Cir. May 1, 1987) (order granting rehearing en banc, which withdrew the panel's opinion and vacated its judgment); see United States v. Klubock, 832 F.2d 664, 665 (en banc) (Torruella, C.J.) (stating that the three judges voting to affirm the district court's decision also "abide by the majority panel opinion"); supra note * (explaining that the half of the en banc court that voted to affirm the district court's decision also adopted the vacated majority panel opinion).

${ }^{42}$ See, e.g., Klubock, 832 F.2d at 657 (upholding Massachusetts rule requiring prior judicial approval before grand jury subpoenas could be served on attorneys); In re Grand Jury Subpoena Served Upon Doe, 759 F.2d 968, 973-75 (2d Cir. 1985) (government must show relevance and reasonable need before issuing a subpoena to attorney to testify before a grand jury against her client), vacated, 781 F.2d 238 (2d Cir. 1986) (en banc); In re Special Grand Jury No. 81-1 (Harvey), 676 F.2d 1005, 100811 (4th Cir.) (a preliminary showing of relevance and need is required before the government can subpoena an attorney to testify before a grand jury), vacated as moot, 697 F.2d 112 (4th Gir. 1982) (en banc); In re Grand Jury Subpoena (Legal Services Center), 615 F. Supp. 958, 964 (D. Mass. 1985) (government has the burden of show- 
sponse has developed primarily in the courts' greater use of their supervisory power. ${ }^{43}$ However, in other areas where increased protection for attorneys might have been found-such as attorney-client privilege, ${ }^{44}$ constitutional protection, ${ }^{45}$ and the use of ethical prohibitions on disclosure of client confidences and secrets ${ }^{\mathbf{4}}$-little development has occurred.

\section{Attorney-Glient Privilege and Work-Product Doctrine}

At one time it might have been thought that the attorney-client privilege, which is an absolute bar under federal law and that of every state, ${ }^{47}$ together with the work-product doctrine, which is a more conditional privilege, ${ }^{48}$ would prevent the use of attorney subpoenas. Although the attorney-client privilege is the oldest of the common law privileges, ${ }^{48}$ its reach has been confined in a variety of ways, and it is no longer safe to assume that the privilege will bar the attorney's testimony. For one thing, in order to invoke the privilege, one must satisfy each of the several requirements of the privilege. As set forth by Professor Wigmore, the factual situation of the party asserting the privilege must meet the following requirements:

(1) Where legal advice of any kind is sought (2) from a professional legal adviser in his capacity as such, (3) the communications relating to that purpose, (4) made in confidence

ing that information subpoenaed was necessary to its investigation, and that it could not gain that information by other reasonable means); In re Grand Jury Matters (Hodes and Gordon), 593 F. Supp. 103, 105-07 (D.N.H.) (subpoenas were invalid where they sought disclosure of attorney-client fee arrangement and where client had state and federal criminal cases pending), aff'd, 751 F.2d 13 (1st Cir. 1984); In re Grand Jury Investigation (Sturgis), 412 F. Supp. 943, 946 (E.D. Pa. 1976) ("work product is a valid ground on which to refuse a grand jury's subpoena"); In re Terkeltoub, $256 \mathrm{~F}$. Supp. 683, 685-86 (S.D.N.Y. 1966) (attorney charged with perjury for denying that he had spoken to a third person was not compelled to testify before a grand jury concerning attorney-client conferences).

43 See infra text accompanying notes 112-116.

4 See infra text accompanying notes 47-55.

45 See infra text accompanying notes 95-111.

46 See infra text accompanying notes 156-169.

47 See J. Backman, supra note 17, at 26.

18 See United States v. Nobles, 422 U.S. 225, 238 (1975) (holding that workproduct doctrine of Hickman v. Taylor, 329 U.S. 495, 508-15 (1947), applies to criminal proceedings). In Nobles, the Court stated that work-product protection is "even more vital" in criminal matters than in civil matters: "The interests of society and the accused in obtaining a fair and accurate resolution of the question of guilt or innocence demand that adequate safeguards assure the thorough preparation and presentation of each side of the case." Id. at 238.

49 See 8 J. Wrgmore, Evidence $\S 2290$ (1983) (discussing the history of the attorney-client privilege). 
(5) by the client, (6) are at his instance permanently protected (7) from disclosure by himself or by the legal adviser, (8) except the protection be waived. ${ }^{\text {so }}$

These requirements leave considerable room, of course, for avoiding the privilege. One of the gaps that prosecutors frequently exploit is the lack of privilege protection for information concerning fees and client identity. ${ }^{51}$ Although the courts have developed several doctrinal approaches to filling this gap, ${ }^{52}$ none provides much certainty that the disclosure of such information cannot be compelled. ${ }^{\text {s3 }}$

A second important exception to the attorney-client privilege is the crime/fraud doctrine, under which communications that would otherwise be privileged lose that protection if they were made for the purpose of committing a crime or fraud. ${ }^{54}$ This exception has been greatly extended in recent years, especially by federal prosecutors, to the point where it has substantially eroded the scope of attorney-client privilege. $^{.55}$

Finally, the conditional privilege for attorney work product is rather limited and subject to many of the same exceptions as attorneyclient privilege. It therefore is not a reliable bar to compelled testimony by the attorney.

so Id. § 2292; see also United States v. United Shoe Mach. Corp., 89 F. Supp. 357, 358-59 (D. Mass. 1950) (Judge Wyzanski's classic formulation of the privilege). See generally $8 \mathrm{~J}$. WIGMORE, supra note 49, ch. 82, $\S \S 2290-2329$ (presenting the eight requirements for "communication between attorney and client").

sx See generally Comment, The Attorney-Client Privilege and the Federal Grand Jury: Client's Identity and Fee Arrangements, 13 AM. J. CRIM. L. 67, 84-85 (1985) (discussing the exceptions to the general rule that clients' identity and fee information do not fall within the attorney-client privilege); Note, Benefactor Defense Before the Grand Jury: The Legal Advice and Incrimination Theories of the Attorney-Client Privilege, 6 CaRdozo L. REv. 537, 539-40 (1985) (examining "whether and when the identity and fee arrangements of a client should be privileged").

${ }^{62}$ See infra text accompanying notes 58-63.

53 See infra note 55 and accompanying text.

s4 See, e.g., In re Sealed Case, 754 F.2d 395, 399 (D.C. Gir. 1985) (communications between attorney and client are not privileged if "made in furtherance of a crime, fraud, or other misconduct"); In re Berkley \& Co., 629 F.2d 548, 553 (8th Cir. 1980) ("Attorney-client communications lose their privileged character when the lawyer is consulted not with respect to past wrongdoings but rather to further a continuing or contemplated criminal or fraudulent scheme."); see also J. WIGMORE, supra note 49, $\S 2298$ (contrasting disclosure of "prior wrongdoing" that is privileged and "future wrongdoing" that is not). See generally Silbert, The Crime-Fraud Exception to the Attorney-Client Privilege and Work-Product Doctrine, the Lawyer's Obligations of Disclosure, and the Lawyer's Response to Accusation of Wrongful Conduct, 23 AM. CRIM. L. Rev. 351 (1986).

os See Fried, supra note 17, at 446. ("[T]he exception has been abused and distorted, above all in the service of federal prosecutors, to the point where the attorneyclient privilege has been seriously eroded.") 


\section{a. Client Identity and Fee Information}

Client identity and fee information have generally been considered to fall outside the scope of attorney-client privilege either because they do not constitute communications relating to the substantive legal advice rendered by the attorney or because they are not confidential. ${ }^{58}$ Since client identity and fee information are present in every case, a rule that always permits the prosecutor to seek such information directly from the attorney gives the prosecutor enormous power, especially when the attorney's response to such inquiries would cause her withdrawal or disqualification. ${ }^{37}$ In an effort to mitigate the harshness of this rule, the courts have developed two distinct rationales for protecting client identity and fee information in certain circumstances. ${ }^{58}$

The narrower rationale, known as the legal advice theory, protects against disclosure of client identity or fee arrangements when such disclosure would be "tantamount to" revealing an "otherwise protected confidential communication." 58 This principle, which has been adopted by a majority of the circuits, limits the type of communications that qualify for protection to those which are necessary to obtain legal advice and "which might not have been made absent the privilege." Under the broader rationale, known as the incrimination theory, an attorney cannot be compelled to disclose such information if it would

56 The client's identity, for example, will not normally be a secret in civil or criminal litigation.

67 Courts have held that client identity and fee information is relevant and needed in a wide variety of cases. See, e.g., In re Grand Jury Subpoena Duces Tecum (Shargel) 742 F.2d 61, 63 (2d Cir. 1984) (government may seek client identity and fee information "as evidence of unexplained wealth which may have been derived from criminal activity, . . . and as evidence of the violation of the tax laws.") Some courts have held that when the government seeks such information from the attorney, it must "show a need for the information sought." In re Grand Jury Proceedings (John Doe, Esq.), 602 F. Supp. 603, 607 (D.R.I.) (citing United States v. Pioggia, Cr. No. 82-231K (D. Mass. Sept. 21, 1983) (Keeton, J.)), aff d sub nom. In re Grand Jury Proceedings (Wilson), 760 F.2d 26 (1st Cir. 1985).

ss Both rationales-the legal advice theory and the incrimination theory-derive from Baird v. Koerner, 279 F.2d 623 (9th Cir. 1960), which neatly exemplifies both theories. In Baird, an attorney was asked to pay back taxes anonymously to the IRS on behalf of his clients. See $i d$. at 626 . The attorney refused to comply with an IRS subpoena seeking the clients' identities, claiming attorney-client privilege. See id. at 627 . The Ninth Circuit upheld the attorney's claim of privilege, see id. at 634-35, noting that disclosure of the client's identity would be tantamount to revealing the substance of the attorney's communication with the clients, see id. at 630, (i.e., legal advice theory), and would also provide the government with the missing link needed to indict the clients, see id. at 633 (i.e., incrimination theory).

${ }^{58}$ See Note, supra note 51, at 555-57 \& n.107 (quoting In re Grand Jury Investigation No. 83-2-35, 723 F.2d 447, 453 (6th Cir. 1983), cert. denied, 467 U.S. 1246 (1984)).

${ }^{80}$ See id. at 556 (citing Fisher v. United States, 425 U.S. 391, 403 (1976)). 
have a "significant incriminatory effect." ity of the circuits has adopted, has developed as a bar to disclosure in two types of situations: (1) where "a strong probability exists that disclosure of such information would implicate that client in the very criminal activity for which legal advice was sought," ${ }^{12}$ and (2) where "the disclosure of the client's identity by his attorney would have supplied the last link in an existing chain of incriminating evidence likely to lead to the client's indictment."

Both rationales provide inadequate protection of the attorney-client relationship. First, neither provides sufficient certainty to permit the would-be client, even a legally sophisticated one, to know whether she can safely retain and confide her identity to the attorney. This is so because both rationales depend ultimately on what the prosecutor knows at the time she seeks to serve or enforce the subpoena. The client generally does not know what information the prosecutor has at any given time, and therefore cannot determine whether her disclosure to the attorney will incriminate her or amount to a disclosure of an otherwise privileged communication.

Second, neither rationale is broad enough to protect the client fully from revelation of matters that are incriminating but completely unrelated to the action at bar. Revelation of the client's identity, for example, might expose the client to prosecution for an offense (such as those related to immigration status) wholly unrelated to the one for which she sought legal advice. Similarly, revelation of fee information might expose the client to prosecution for income tax offenses which, again, are completely unrelated to the matter for which she sought representation.

Finally, because both of these rationales offer increasing protection for client identity and fee information as the prosecutor learns more about the client, they provide the prosecutor with the perverse incentive to subpoena the attorney during the early stages of a grand jury investigation, even though further investigation might reveal non-attorney sources for the information sought from the attorney. ${ }^{64}$ In short, neither rationale provides much of a bulwark against the use of attorney sub-

61 See Note, supra note 51, at 553-55.

${ }^{62}$ United States v. Hodge \& Zweig, 548 F.2d 1347, 1353 (9th Cir. 1977). (en banc).

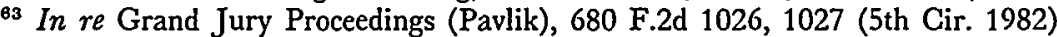

64 See Case Comment, The Attorney-Client Privilege as a Protection of Client Identity: Can Defense Attorneys be the Prosecution's Best Witnesses?, In re Grand Jury Proceedings (Pavlick), 21 AM. CRIM. L. Rev. 81, 91 (1983); Note, supra note 51, at 571 . 
poenas; they may in fact be counterproductive. ${ }^{65}$

\section{b. Crime/Fraud Exception}

Use of the crime/fraud exception by prosecutors as a means of compelling attorney testimony has "skyrocketed" in the past few years. ${ }^{68}$ The exception's usefulness to prosecutors is readily apparent since it not only sweeps away the various rationales for barring the disclosure of client identity and fee information, ${ }^{67}$ but negates the privilege altogether, thus potentially making available to the prosecutor all communications between the attorney and client. ${ }^{68}$

Given the enormous power of this exception as a prosecutorial tool, one would expect the courts to have erected rather steep barriers to its successful invocation. Yet a review of the cases suggests precisely the opposite. Courts often permit the crime/fraud exception to be established on the basis of an in camera or ex parte showing. ${ }^{69}$ Some courts require only a prima facie showing by the prosecutor. ${ }^{70}$ In some circuits, the prosecutor, in order to establish a prima facie case, need not adduce any independent evidence beyond the statement or information that she is seeking to elicit. ${ }^{71}$ Moreover, on appeal, the trial court's decision to apply this exception and allow full disclosure of attorneyclient communications is generally reviewed under a deferential "abuse

6s See Developments in the Law, Privileged Communications, 98 HaRv. L. REv. $1450,1522-24$ (1985) (arguing that client identity and fee information should be considered privileged communications subject to an intent-based crime/fraud exception).

${ }^{68}$ See J. Backman, supra note 17 , at 50.

67 See Fried, supra note 17, at 485-86.

${ }_{68}$ See, e.g., United States v. Horvath, 731 F.2d 557, 562 (8th Cir. 1984) (noting, first, that attorney-client communications become non-privileged when attorney is consulted to further a prospective crime or fraud, and second, that consultation regarding past crimes becomes inseparable from the consultation regarding prospective crimes). Some courts have held that in order to invoke successfully the crime/fraud exception, the prosecutor must show a nexus between the alleged unlawful scheme and the attorney-client communications the disclosure of which is being sought. See, e.g., In re Sealed Case, 754 F.2d 395, 399 (D.C. Cir. 1985) ("government must first make a prima facie showing of a violation sufficiently serious to defeat the privilege, and second, establish some relationship between the communication at issue and the prima facie violation" (footnote omitted)).

${ }^{69}$ See Silbert, supra note 54, at 362-64 \& nn.88-89.

${ }^{70}$ See, e.g., Clark v. United States, 289 U.S. 1, 15 (1933) (discussing the prima facie evidence standard in earler cases); In re Grand Jury Proceedings (Vargas), 723 F.2d 1461, 1467 (10th Cir. 1983) (analyzing the determination of the prima facie evidence standard), enforced, 727 F.2d 941, 946 (10th Cir.), cert. denied, 469 U.S. 819 (1984).

${ }^{71}$ See Fried, supra note 17, at 464-66; Silbert, supra note 54, at 365-67. But see United States v. Shewfelt, 455 F.2d 836, 840 (9th Cir.) (requiring that "government must first establish a prima facie case of fraud independently of the said communications"), cert. denied, 406 U.S. 944 (1972). 
of discretion" standard, which makes reversals unlikely. ${ }^{\mathbf{7 2}}$

Even more disturbing, however, is the tendency of the exception to swallow up the rule of attorney-client privilege altogether. In United States $v$. Horvath, ${ }^{73}$ for example, the court held that the crime/fraud exception is satisfied when the "primary purpose" of the attorney-client relationship was to "conceal from the government the extent of [the client's] financial holdings and [the client's] sources of income.""74 Under such a standard, the attorney must walk an increasingly fine line indeed between the path of zealous advocacy that her ethical duties require and a course that leads her to become a grand jury target or a witness against her client. Moreover, if concealment of information (e.g., "benefactor" payments) by the attorney is viewed as an act "in furtherance of" the criminal activity, the exception does in fact swallow the rule since the criminal activity might then be considered "on-going" as long as the attorney and her client continue to conceal the information. ${ }^{75}$

As this brief sketch indicates, the crime/fraud exception further weakens the protections of the attorney-client privilege and provides another means by which the attorney can be compelled to testify against her client.

\section{c. Work-Product Doctrine}

The need to protect attorney work product, and the subsequent creation of a "work-product" rule, arose with the advent of pretrial discovery. In the civil context, broad pretrial discovery began with the adoption of the Federal Rules of Civil Procedure in $1938 .{ }^{76}$ The rules limiting the use of civil discovery techniques to obtain attorney work product followed with the Supreme Court's decision in Hickman v. Taylor 77 in 1947 and the adoption of Federal Rule of Civil Procedure $26(b)(3)$ in $1970 .^{78}$

72 See Silbert, supra note 54 , at 364 \& n.97.

73731 F.2d 557 (8th Cir. 1984).

${ }^{74} I d$. at 562 . Although the Horvath court relied on the finding that the concealment served to facilitate "an ongoing criminal conspiracy," once the court concluded that the crime/fraud exception applied, it decided that the attorney could therefore be compelled to testify about past, as well as "ongoing" crimes. Id.

${ }_{75}$ See Note, supra note 51 , at $579-80$ (tracing problems that flow from construing "benefactor" payments as an act of concealment that extends the duration of the conspiracy).

${ }^{78}$ See annual Report of the Attorney General of the United States FOR THE FISCAL YEAR ENDED June 30, 1938 at 1-2 (describing the history of the adoption of the rules of civil procedure).

77329 U.S. 495 (1947).

${ }^{78}$ See Feldman, The Work Product Rule in Criminal Practice and Procedure, 
In federal criminal cases, the work-product rule derives from Hickman, as modified in 1966 by Federal Rule of Criminal Procedure $16(b)(2)$, which creates an absolute bar to discovery of certain types of tangible trial preparation material. ${ }^{79}$ In United States $v$. Nobles, ${ }^{80}$ the Court made it clear that Hickman applied to criminal as well as civil cases, but that Rule 16(b) applied only to pretrial discovery. ${ }^{81}$ Thus, in determining the precise scope of the work-product protection for criminal defendants, one must look to the overlapping and sometimes conflicting lines of authority deriving from Hickman, Nobles, and Rule $16^{82}$

Work-product protection is important because neither the attorney-client privilege nor the fifth amendment necessarily bars discovery of the materials that an attorney prepares and collects. As noted above, attorney-client privilege protects from disclosure only communications between the client and attorney-neither information obtained by the attorney from third parties, nor documents from any source (unless they are attorney-client communications) are protected. Moreover, the fifth amendment applies only to statements compelled from the lips or files of the defendant herself rather than from the lips or files of her attorney ${ }^{\mathbf{8 3}}$ Notwithstanding the need for broad protection in this area, however, a review of the work-product doctrine indicates that the privilege is a rather limited one, at least from the standpoint of resisting an attorney subpoena.

First, the doctrine pertains only to materials prepared in anticipa-

50 U. GiN. L. REv. 495, 504-06 \& n.33 (1981). For a discussion, and a graphic illustration of the ways in which Fed. R. Civ. P. 26(b)(3) differs from Hickman, see generally Clermont, Surveying Work Product, 68 CoRneld L. Rev. 755, 755-56 (1983) (stating that the situation after Hickman is even more confusing than before).

${ }_{70}$ Rule $16(\mathrm{~b})(2)$ was promulgated as part of Rule 16(c) in 1966, was relocated in 1975, and was made gender-neutral in 1987. It now states:

Information Not Subject to Disclosure. Except as to scientific or medical reports, this subdivision does not authorize the discovery or inspection of reports, memoranda, or other internal defense documents made by the defendant, or the defendant's attorneys or agents in connection with the investigation or defense of the case, or of statements made by the defendant, or by government or defense witnesses, or by prospective government or defense witnesses, to the defendant, or the defendant's agents or attorneys.

FED. R. CRIM. P. 16(b)(2).

80422 U.S. 225 (1975).

81 See id. at 234-40 (prosecution was entitled to inspect at trial a report prepared by a defendant's investigator because (1) Rule 16(b) did not limit production of such documents at the time of trial, and (2) the relevant work-product protection under Hickman had been waived by the investigator's testifying at trial).

82 Although a detailed discussion of the availability of work-product protection in state criminal proceedings lies outside the scope of this Article, such protection is available in a majority of states. See Feldman, supra note 78 , at 495 \& n.5.

${ }^{83}$ See Fisher v. United States, 425 U.S. 391, 405-14 (1976). 
tion of litigation. ${ }^{84}$ This limitation leaves open to discovery all materials accumulated by the lawyer at a stage not involving litigation or in matters not related to any litigation. ${ }^{85}$ Also, as noted above, much of the material sought by prosecutors through attorney subpoenas relates to tax advice, real estate transactions, and other matters not necessarily related to litigation, ${ }^{\mathbf{8}}$ and therefore would often not be covered by the work-product rule.

Second, even though work-product privilege can be asserted by either the attorney or the client, ${ }^{87}$ the client may not be aware of the existence of the attorney subpoena and therefore may not be able to assert the privilege at a time when it is needed.

Third, for material covered by the Hickman-Nobles line of cases rather than by Rule 16 (i.e., intangible work product), the privilege is a qualified one that arguably can be overcome upon a proper showing of need by the prosecution. Indeed, even the protection for opinion workproduct has been held not to be absolute. ${ }^{88}$

Fourth, the crime/fraud exception to the attorney-client privilege applies to the work-product privilege. Thus the prosecution could seek to open the door to all defense materials, written or unwritten (except possibly mental impressions of the attorney), upon a prima facie showing of crime or fraud. ${ }^{89}$

Fifth, it is not clear that the work-product privilege continues after the representation in which the material was accumulated ends. ${ }^{90}$

Finally, a decision adverse to the defendant's rights under the work-product doctrine will seldom be challenged successfully on appeal because the courts typically view such decisions as within "the wideranging discretion of the trial judge."

Taken together these limitations suggest that in the attorney subpoena setting the work-product doctrine will often fail in its essential purpose-the creation of a zone of privacy within which the attorney can represent the client's interests "free from unnecessary intrusion by

84 See Hickman, 329 U.S. at 510; FED. R. CRIM. P. 16(b).

80 See J. Backman, supra note 17 , at 32 .

${ }^{86}$ See supra note 21 and accompanying text; supra note 19.

87 See Silbert, supra note 54 , at 359.

88 See Upjohn Co. v. United States, 449 U.S. 383, 401-02 (1981).

${ }^{89}$ See In re Special September Grand Jury (II), 640 F.2d 49, 63 (7th Gir. 1980); In re Grand Jury Proceedings (FMC Corp.), 604 F.2d 798, 802-03 (3d Cir. 1979); In re Grand Jury Proceedings (John Doe, Esq.), 602 F. Supp. 603, 607-08 (D.R.I. 1985). See generally Silbert, supra note 54 at 355-58 (discussing the work-product privilege and the crime/fraud exception).

${ }_{80}$ See generally Note, The Work Product Doctrine in Subsequent Litigation, 83 Colum. L. Rev. 412, 421-24 (1983) (noting split of authority on this question).

21 See Feldman, supra note 78 , at 511 \& n.74. 
opposing parties and their counsel."

\section{d. Conclusion}

Today, when a client consults an attorney for legal advice, the attorney can no longer confidently tell the client that all the information entrusted to the attorney is privileged and therefore will be kept in strict confidence. The traditional expectations about the scope of the attorney-client and work-product privilege no longer hold true. ${ }^{93}$ Indeed, more than one commentator has suggested that under the emerging case law of "no attorney-client privilege," the attorney would be well advised to give each new client a Miranda-like warning about the manner in which the client's disclosures to the attorney could be used against her by means of forced disclosure from the mouth of the attorney $!^{\mathbf{9 4}}$ In short, judicial developments in the area of attorney-client and work-product privilege have, if anything, undermined rather than strengthened attorneys' ability to challenge attorney subpoenas.

\section{Constitutional Protection}

A number of attorneys and commentators have looked to the protections afforded by the fifth and sixth amendments to the United States Constitution as a bulwark against the increasing use of attorney subpoenas. For example, attorneys have frequently-and sometimes successfully-fought subpoenas on the ground that the attorney's likely subsequent disqualification would infringe her client's sixth amendment right to counsel. ${ }^{95}$

This argument was accepted in United States $v$. Diozzi, where the First Circuit noted that although the defendant's constitutional right to be represented by counsel of choice is a qualified (not absolute) right, the government "bears a heavy burden" of justification if it seeks to disqualify counsel on the ground that her testimony is needed at trial. ${ }^{96}$ Indeed, the Diozzi court went on to hold that an erroneous order disqualifying counsel from a criminal case should result in an automatic reversal, without any showing of prejudice by the defendant. ${ }^{97}$

${ }^{92}$ Nobles, 422 U.S. at 237 (quoting Hickman, 329 U.S. at 510-11).

${ }^{83}$ See supra notes $42-92$ and accompanying text.

94 See Fried, supra note 17, at 491 n.270; Note, supra note 51, at 568 n.171.

95 See, e.g., United States v. Diozzi, 807 F.2d 10, 15-16 (1st Cir. 1986) (government must "justify" any request to disturb a criminal defendant's constitutional right to counsel of choice). For a brief discussion of a civil litigant's constitutional right to counsel, see Potashnick v. Port Gity Constr. Co., 609 F.2d 1101, 1118-19 (5th Cir. 1980).

${ }^{86}$ See Diozzi, 807 F.2d at 12.

${ }^{97}$ See id. at 15-16; see also Richardson-Merrell, Inc. v. Koller, 472 U.S. 424, 443 
Most courts faced with a motion to disqualify a defendant's attorney, however, tend to balance the harm to the client and the infringement of her sixth amendment right to counsel against the government's need for the attorney's testimony and the need to enforce ethical standards barring the attorney from serving as advocate and witness. ${ }^{88} \mathrm{Bal}-$ ancing these interests, courts have reached a variety of results, including partial disqualification and disqualification of some but not all of the attorneys involved in a case. ${ }^{90}$

In a number of cases, courts have relied on sixth amendment concerns as the basis for overturning decisions to disqualify a defendant's counsel of choice. ${ }^{100}$ Such a result is consistent with the long-standing

(1985) (Stevens, J., dissenting on other grounds) ("in a criminal case an erroneous order disqualifying the lawyer chosen by the defendant should result in a virtually automatic reversal"); Linton v. Perini, 656 F.2d 207, 211-12 (6th Cir. 1981) (harmless error rule does not apply when court effectively deprived defendant counsel of choice by unreasonably denying motion for continuance), cert denied, 454 U.S. 1162 (1982); Releford v. United States, 288 F.2d 298, 301-02 (9th Cir. 1961) (no showing of prejudice required where court refused to grant continuance to defendant whose retained counsel was hospitalized). It is, of course, well settled that the denial of counsel altogether is grounds for automatic reversal, without any showing of prejudice. See Strickland v. Washington, 466 U.S. 668, 692 (1984); United States v. Cronic, 466 U.S. 648, 659 n.25 (1984); Chandler v. Fretag, 348 U.S. 3, 9-10 (1954).

${ }_{88}$ See, e.g., United States v. Cunningham, 672 F.2d 1064, 1070 (2d Cir. 1982) (balancing defendant's right to counsel of choice against "the need to preserve the highest ethical standards of professional responsibility"), cert. denied, 466 U.S. 951 (1984); United States v. Garcia, 517 F.2d 272, 273 (5th Cir. 1975) (disqualification motion calls for "cautious and sensitive consideration and balancing of individual constitutional protections, public policy and public interest in the administration of justice, and basic concepts of fundamental fairness"). A similar analysis is used by the courts in determining whether to allow forfeiture, under 21 U.S.C. § 853 (Supp. III 1985 \& West Supp. 1987), of the funds that a defendant seeks to use for attorney's fees. See, e.g., United States v. Harvey, 814 F.2d 905, 923-25 (4th Cir. 1987) (balancing individual interests against government interests); United States v. Thier, 801 F.2d 1463, 1471-72 (5th Cir. 1986) (same).

99 See, e.g., United States v. Agosto, 675 F.2d 965, 975-77 (8th Cir. 1982) (reversing one attorney's disqualification but upholding another's); United States v. Dolan, 570 F.2d 1177, 1184 (3d Cir. 1978) (upholding disqualification of defense counsel); Garcia, 517 F.2d at 272 (reversing disqualification order); United States v. Castellano, 610 F. Supp. 1151, 1167-68 (S.D.N.Y. 1985) (permitting defense counsel to continue representation of criminal defendant in all phases of the litigation except at trial, where counsel could be present but not at counsel table).

Ironically, the principle on which several of these courts disagree is whether the constitutional right to counsel of choice includes the ability to waive the right to assistance of an attorney who either is a potential witness or has a conflict of interest. Compare Garcia, 517 F.2d at 272 (client can waive that right) with Dolan, 570 F.2d at 1177 (client cannot waive that right). The fact that criminal defendants, when faced with the decision whether to give up their counsel of choice or stick with an attorney who may be compelled to testify against them, often choose the latter, poignantly suggests the need for regulation of the government's use of defense attorneys as witnesses.

100 See, e.g., United States v. Washington, 797 F.2d 1461 (9th Cir. 1986); Cunningham, 672 F.2d at 1070 . Unfortunately, such decisions have limited value in the grand jury setting, where the client's sixth amendment rights have not yet attached. See 
principle that the sixth amendment right to counsel entails the right to independent counsel not subject to governmental control. ${ }^{101}$ Such a result also reflects the practical reality that one of the most important decisions that a criminal defendant makes is her choice of counsel. ${ }^{\mathbf{1 0 2}}$

Several commentators have suggested that the sixth amendment right to counsel, when taken together with the fifth amendment's protection against forced self-incrimination, makes the attorney-client privilege a constitutional imperative. ${ }^{103}$ Other commentators have built on the holding in Fisher $v$. United States ${ }^{104}$ to argue that client identity and fee information, which have generally been considered nonprivileged, ${ }^{105}$ are entitled to "constitutionalized" protection under the attorney-client privilege because if the client could not be compelled to dis-

Kirby v. Illinois, 406 U.S. 682, 689-90 (1972) (holding that sixth amendment right to counsel does not attach until the criminal prosecution commences). Even so, the Supreme Court has never squarely addressed the question of whether a grand jury witness has a right to counsel. See United States v. Mandujano, 425 U.S. 564, 603 (1976) (Brennan, J., concurring). But see In re Groban, 352 U.S. 330, 333 (1957) (dictum denying that grand jury witnesses have the right to counsel). It is worth noting that fifteen states now permit grand jury witnesses the right to have counsel in the grand jury room. See Comment, Grand Jury-Attorney-Client Privilege and Right to Counsel for the Party Under Investigation, In re Special Grand Jury No. 81-1 (Harvey), 19 WAKE FOREST L. Rev. 487, 509 n.178 (1983).

${ }^{101}$ See Polk County v. Dodson, 454 U.S. 312, 321 (1981) ("Implicit in the concept [of a defendant's right to have counsel at every step in a proceeding] . . . is the assumption that counsel will be free of state control." (emphasis added)); Ferri v. Ackerman, 444 U.S. 193, 204 (1979) ("indispensable element of the effective performance of [appointed counsel's] responsibilities is the ability to act independently of the Government" (emphasis added)); United States v. Klubock, 832 F.2d 649, 645 (1st Cir. 1987) (sixth amendment rights implicated by use of attorney subpoenas because "prosecutor is potentially given control over who shall be his attorney/adversary"), vacated, United States v. Klubock, No. 86-1413 (1st Cir. May 1, 1987) (order granting rehearing en banc, which withdrew the panel's opinion and vacated its judgment); see also United States v. Klubock, 832 F.2d 664, 665 (en banc) (Torruella, C.J.) (stating that the three judges voting to affirm the district court's decision also "abide by the majority panel opinion"); supra note * (explaining that the half of the en banc court that voted to affirm the district court's decision also adopted the vacated majority panel opinion).

${ }^{102}$ See United States v. Rankin, 779 F.2d 956, 958 (3d Cir. 1986) (recognizing the importance of the defendant's selection of counsel to her ability to shape a defense); United States v. Laura, 607 F.2d 52, 55 (3d Cir. 1979) (noting that "attorneys are not fungible"); Note, Second Circuit Rejects Need Requirement for Attorney Subpoena, In re Grand Jury Subpoena Served Upon John Doe, Esq. (Slotnick) 60 Sr. JoHN's L. REV. 524, 525 n.3 (1986).

${ }_{103}$ See, e.g., Rosenfeld, The Transformation of the Attorney-Client Privilege: In Search of an Ideological Reconciliation of Individualism, the Adversary System, and the Corporate Client's SEC Disclosure Obligations, 33 Hastings L.J. 495, 510-11 \& n.89 (1982) (citing authority for the constitutionalization of the attorney-client privilege); Note, supra note 51, at 567-68 (arguing that permitting an attorney to testify conflicts with a defendant's right against self-incrimination).

104425 U.S. 391, 396 (1976) (holding that the attorney-client privilege, not the fifth amendment, protects attorneys from forced disclosure of material that clients would have a fifth amendment right not to produce).

${ }_{108}$ See supra notes 56-65. 
close such information, neither can the attorney. ${ }^{106}$

Although these theories of broader constitutional protection of the attorney-client relationship would provide a powerful rationale for regulating attorney subpoenas, the courts have generally alluded to sixth amendment concerns as merely "implicated" by attorney subpoenas. ${ }^{107}$ The courts typically have relied on their supervisory power rather than the Constitution as the legal basis for limiting the use of attorney subpoenas and thus preventing disqualification. ${ }^{108}$ On the other hand, state constitutions, which generally include a right to counsel at least as broad as that contained in the federal Constitution, ${ }^{109}$ have in some cases been interpreted as barring the use of a criminal defendant's attorney as a witness against her. ${ }^{110}$ Thus, there may be reason for optimism that state constitutional development could play a significant role in regulating attorney subpoenas. ${ }^{111}$

\section{Supervisory Power}

Even before the adoption of Federal Rule of Criminal Procedure 17(c), which authorizes courts to quash subpoenas where "compliance

${ }^{108}$ See Glanzer \& Taskier, supra note 17, at 1096-98.

107 Compare, e.g., United States v. Klubock, 832 F.2d 649, 645 (1st Cir. 1987) (divided panel) (sixth amendment rights implicated by use of attorney subpoenas), affg 639 F. Supp 117 (D. Mass. 1986), vacated, 832 F.2d 664 (1st Cir. 1987) (en banc) (equally divided court affirming district court opinion and citing panel opinions) with In re Grand Jury Subpoena Served Upon Doe, 759 F.2d 968, 971 (2d Cir. 1985) (noting that the preliminary showing requirement is not compelled by the sixth amendment) and In re Special Grand Jury No. 81-1 (Harvey), 676 F.2d 1005, 1012 (4th Cir.) (same), vacated as moot, 697 F.2d 112 (4th Cir. 1982) (en banc).

${ }_{108}$ See infra text accompanying notes 112-69.

109 See, e.g., ARK. CoNST. art. II, $\S 10$ (right to be heard "by himself and his counsel") (emphasis added); LA. ConST. art. I, $\S 13$ ("[a]t each stage of the proceedings, every person is entitled to assistance of counsel of his choice" (emphasis added)); TENN. CoNST. art. I, $\S 9$; (same language as Arkansas). Cf. W. VA. Const. art. III, $\S 14$ (defendant entitled to "reasonable time to prepare for his defense").

11 See, e.g., Kaeser v. State, 620 P.2d 872, 874 (Nev. 1980) (mere testimony by defendant's counsel did not violate defendant's right to fair trial, but trial court violated state constitution's right to counsel provision by allowing state to call defendant's attorney as witness to impeach alibi testimony); State v. Thomas, 53 Or. App. 375, 380-81, 631 P.2d 1387, 1391 (1981) (same). For a discussion of the development of state constitutional principles as an autonomous body of law, separate from federal constitutional law, see Brennan, State Constitutions and the Protection of Individual Rights, 90 HARV. L. REv. 489 (1977).

11 Query whether a state constitutional right to counsel can limit federal prosecutors' use of attorney subpoenas: the supremacy clause and federalism issues that such an approach raises resemble the issues raised in Klubock about applying a state ethical rule if that rule has not also been adopted by the federal courts in that district. See infra notes 195-96 and accompanying text. A similar problem could arise if the applicable state and federal rules were identical but were interpreted more restrictively by the state courts. 
would be unreasonable or oppressive,"112 federal courts exercised their inherent supervisory power over grand juries to curb abuses. ${ }^{113}$ Courts responded to particular types of prosecutorial misconduct, such as the knowing use of false or perjured testimony, by dismissing indictments or quashing subpoenas. ${ }^{114}$ In the context of attorney subpoenas, a number of courts have employed their supervisory powers to establish a requirement that the government make a preliminary showing before an attorney subpoena would be enforced or before the subpoena could be served on the attorney. ${ }^{115}$

The three most prominent decisions in this area came from the First, Second, and Fourth Circuits, which have reached arguably inconsistent conclusions with respect to the use of supervisory power to regulate attorney subpoenas. ${ }^{116}$ In each of these circuits, the courts have either overturned panel decisions or issued opinions with sharply worded dissents-all of which indicates the highly unsettled state of the

112 FED. R. CRIM. P. 17(c).

113 See McNabb v. United States, 318 U.S. 332, 340 (1943) (district courts' supervision of grand juries includes the duty of "establishing and maintaining civilized standards of procedure and evidence"); see also Fay v. New York, 332 U.S. 261, 297 (1947) (Murphy, J., dissenting).

114 See United States v. Hogan, 712 F.2d 757, 762 (2d Cir. 1983); United States v. Asdrubal-Herrera, 470 F. Supp. 939 , 942-43 (N.D. Ill. 1979); United States v. Gallo, 394 F. Supp. 310, 315 (D. Conn. 1975).

115 See, e.g., In re Grand Jury Subpoena (Legal Services Center), 615 F. Supp. 958, 964 (D. Mass. 1985) (approving requirement of prior judicial approval of attorney subpoena); In re Punelli, Misc. No. 1-39, slip op., (S.D. Iowa Sept. 17, 1985) (same) (on file with the University of Pennsylvania Law Review); United States v. Pioggia, No. 82-231-K, slip op., (D. Mass. Sept. 21, 1983) (same) (on file with the University of Pennsylvania Law Review); see also Williams v. District Court, 700 P.2d 549, 554-56 (Colo. 1985) (en banc) (prosecutor must make preliminary showing of need for attorney subpoena).

A number of courts have stated that a preliminary showing of need could be required under the court's supervisory power, but declined to establish such a rule on the facts then before the court. See e.g., In re Grand Jury Proceeding (Schofield), 721 F.2d 1221,1222 \& n.1 (9th Cir. 1983) (court is free to require preliminary showing of need and relevance of attorney subpoena but declines to do so on facts of present case); In re Pantojas, 628 F.2d 701, 705 (1st Cir. 1980) (declining to "impose [such a rule] on district courts within the circuit at this time" but stating that "[d]istrict courts should . . - feel free to require such showings by the government as a means of assuring themselves that grand juries are not overreaching") (emphasis added).

116 See United States v. Klubock, 832 F.2d 649 (1st Gir. 1987), vacated, United States v. Klubock, No. 86-1413 (1st Cir. May 1, 1987) (order granting rehearing en banc, which withdrew the panel's opinion and vacated its judgment); see also United States v. Klubock, 832 F.2d 664, 665 (en banc) (Torruella, C.J.) (stating that the three judges voting to affirm the district court's decision also "abide by the majority panel opinion"); supra note * (explaining that the half of the en banc court that voted to affirm the district court's decision also adopted the vacated majority panel opinion); In re Grand Jury Subpoena Served Upon Doe, 759 F.2d 968 (2d Gir. 1985), vacated, 781 F.2d 238 (2d Cir. 1986) (en banc); In re Special Grand Jury No. 81-1 (Harvey), 676 F.2d 1005 (4th Gir), vacated as moot, 697 F.2d 112 (4th Gir. 1982) (en banc). 
law on this subject.

\section{a. Doe and Harvey}

In Doe and Harvey, the Second and Fourth Gircuits reversed or vacated decisions in which panels required a showing of need and relevance as a prerequisite for enforcing an attorney subpoena. In both cases, the panel decision had held that such a requirement was necessary to protect the attorney-client relationship because of the inadequacy of the protection afforded by the attorney-client privilege. ${ }^{117} \mathrm{Al}$ though neither of these opinions remains the law in its respective circuit-Doe was reversed en banc and Harvey was vacated as moot ${ }^{118}$ - the rationale of those decisions retains its force and has been relied on by other courts. ${ }^{119}$ Nevertheless, the overwhelming trend in the federal courts has been a rejection of a preliminary showing requirement for attorney subpoenas. Indeed, except for the Third and possibly the Tenth Circuit, every circuit that has considered creating such a requirement has declined to do so. ${ }^{120}$ In those two circuits, the courts require the government to make a preliminary showing of need and relevance in order to obtain enforcement of all grand jury subpoe-

117 Doe, 759 F.2d at 975 (holding that "when a subpoena is issued to an attorney to testify before a grand jury investigating his client . . . where the attorney will be disqualified if he testifies, the Government should make a preliminary showing of relevance and reasonable need" to maintain "the integrity of the attorney-client relationship"); Harvey, 676 F.2d at 1012 ("preliminary showing . . . is appropriate to protect a person's interest in maintaining a proper attorney-client relationship").

${ }^{118}$ According to Judge Murnaghan, who dissented from the panel decision in Harvey, the Fourth Circuit was likely to reverse the panel opinion when the target fled the jurisdiction and the case was rendered moot. See United States v. Morchower, No. 83-1816 (4th Cir. Sept. 28, 1983), slip op. at 405, cited in In re Grand Jury Subpoena Served Upon Doe, 781 F.2d 238, 247 n.4 (2d Cir.) (en banc), cert. denied, 475 U.S. 1108 (1986).

${ }^{119}$ See, e.g., In re Grand Jury Subpoena (Legal Services Center), 615 F. Supp. at 964 ("[m]indful of importance of the attorney-client relationship to our system of justice, the Court adopts the reasoning of Harvey and Doe" and requires preliminary showing of need).

${ }_{120}$ See In re Grand Jury Proceedings (85 Misc. 140), 791 F.2d 663, 665 (8th Cir. 1986); In re Certain Complaints Under Investigation, 783 F.2d 1488, 1525 (11th Gir.), cert. denied, 106 S.Ct. 3273 (1986); In re Grand Jury Subpoena Served Upon Doe, 781 F.2d at 243; In re Klein, 776 F.2d 628, 634 (7th Cir. 1985); In re Grand Jury Proceedings (Weiner), 754 F.2d 154, 156 (6th Cir. 1985); In re Grand Jury Proceeding (Schofield), 721 F.2d 1221, 1223 (9th Cir. 1983); In re Grand Jury Proceedings (Freeman), 708 F.2d 1571, 1575 (11th Cir. 1983); In re Walsh, 623 F.2d 489, 493 (7th Cir.), cert. denied, 449 U.S. 994 (1980).

It is noteworthy that in none of these cases did the court hold that it lacked the authority, under its supervisory powers, to adopt a need and relevance requirement. On the other hand, these cases demonstrate a clear disinclination to use supervisory powers to carve out a special rule for attorney subpoenas. See, e.g., In re Klein, supra, at 634 (calling requirement of preliminary showing "a thoroughly bad idea"). 
nas regardless of whether they are directed to attorneys or others. ${ }^{121}$

The courts that have rejected a need and relevance test for attorney subpoenas have relied primarily on a line of Supreme Court cases that have emphasized the broad nature of the grand jury's inquiry and its historic freedom from outside interference. The cases most frequently cited are United States $v$. Dionisio ${ }^{\mathbf{1 2 2}}$ and Branzburg $v$. Hayes. ${ }^{123}$ An examination of those two cases, however, suggests that neither one stands in the way of courts that wish to adopt a preliminary showing requirement.

In Dionisio, the Supreme Court held that requiring production of voice exemplars during grand jury proceedings did not violate the witness's rights under the fourth and fifth amendments. ${ }^{124}$ The portion of Dionisio relied on by those courts that have rejected a preliminary showing requirement for attorney subpoenas is a widely quoted dictum that "[a]ny holding that would saddle a grand jury with minitrials and preliminary showings would assuredly impede its investigation and frustrate the public's interest in the fair and expeditious administration of the criminal laws." ${ }^{25}$ Yet nothing in Dionisio would prohibit federal courts from adopting prophylactic rules such as those that have been adopted by other courts to regulate the use of attorney subpoenas. ${ }^{\mathbf{1 2 6}}$ Rather, Dionisio cautions that in exercising their supervisory powers over the grand jury, federal courts should avoid measures that hamper the grand jury's performance of its lawful duties. ${ }^{127}$ Moreover, the rationale cited in Dionisio for steering clear of the grand jury's work-namely, the grand jury's historic independence and its dual role as protector of the public against abusive prosecutions and an investigative arm of the prosecution ${ }^{\mathbf{1 2 8}}$ — has in recent years been called sharply

121 In re Grand Jury Proceedings (Schofield II), 507 F.2d 963, 965 (3d Cir. 1975), cert. denied, 421 U.S. 1015 (1975); in re Grand Jury Proceedings (Schofield I), 486 F.2d 85, 93 (3d Cir. 1973), cert. denied, 462 U.S. 1119 (1983). The Tenth Circuit, citing Schofield $I$, has required a preliminary showing of relevance and "proper purpose" before enforcement of a grand jury subpoena would be allowed. In re Grand Jury Subpoena Duces Tecum (Dorokee Co.), 697 F.2d 277, 281 (10th Cir. 1983).

122410 U.S. 1 (1973).

123408 U.S. 665 (1972).

124 Dionisio's holding that a preliminary showing of the prosecutor's need for voice exemplars is not affirmatively required by the fourth or fifth amendments is hardly surprising given the Court's conclusion that neither amendment was relevant to the compelled production of such exemplars. See Dionisio, 410 U.S. at 5, 10.

125 Id. at 17.

126 See supra notes 112-115 and accompanying text.

${ }^{127}$ Of course, notwithstanding this caution, courts have recognized that the privileges which protect the attorney-client relationship apply in the grand jury room.

${ }_{128}$ See Dionisio, 410 U.S. at 12-13; see also United States v. Sells Eng'g, 463 U.S. 418, 424 (1983); Branzburg, 408 U.S. at 688. 
into question. ${ }^{129}$

In Branzburg, the Supreme Court held that the first amendment does not give reporters a blanket privilege against appearing and testifying before a grand jury. Of course, this holding does not stand in the way of a court's using its supervisory power to require a preliminary showing before enforcing a grand jury subpoena directed to attorneys or reporters. Indeed, as Justice Powell's concurrence points out, reporters may still look to the courts' supervisory power for protection if "the grand jury investigation is not being conducted in good faith." 130 Moreover, the majority acknowledges the possibility that such a privilege could be created by federal or state legislation. ${ }^{131}$

Notwithstanding the weakness of the rationale for rejecting the use of supervisory power to require a preliminary showing for enforcement of attorney subpoenas, the majority of circuits have so far declined to adopt such a requirement as a general matter. ${ }^{132}$

\section{b. United States v. Klubock}

The attorney subpoena issue has been litigated in the First Circuit in a context markedly different from that in which the issue arose in the Second and Fourth Circuits. Rather than ruling on the enforcement of a particular attorney subpoena, the First Circuit ${ }^{133}$ has examined the question of whether the District Court for the District of Massachusetts may, as an exercise of its supervisory or rulemaking power, adopt a local rule known as Prosecutorial Function 15 or "PF 15,"

128 In particular, attorneys and commentators have questioned whether the grand jury retains any vestige of independence from the prosecutor. See infra text accompanying notes 165-68.

${ }_{130}$ Branzburg, 408 U.S. at 710 (Powell, J., concurring).

131 See id. at 689. In applying Branzburg, the Third Circuit held that, even in the absence of an absolute first amendment privilege for reporters, courts are free to adopt a common law privilege for reporters. See United States v. Cuthbertson, 630 F.2d 139, 146 (3d Cir. 1980), cert. denied, 449 U.S. 1126 (1981); Riley v. Gity of Chester, 612 F.2d 708, 715 (3d Cir. 1979). In addition, at least one circuit has held that a qualified privilege is available to reporters in grand jury proceedings. See Bursey v. United States, 466 F.2d 1059, 1075-78 (9th Cir. 1972).

${ }^{132}$ It is worth noting, however, that whatever constraints the federal courts may feel due to Dionisio and its progeny, do not apply to state courts. The latter are, of course, free to strike a different balance in overseeing grand juries.

${ }^{133}$ See United States v. Klubock, 832 F.2d 649 (1st Cir. 1987), vacated, United States v. Klubock, No. 86-1413 (1st. Cir. May 1, 1987) (order granting rehearing en banc, which withdrew the panel's opinion and vacated its judgment); see also United States v. Klubock, 832 F.2d 664, 665 (en banc) (Torruella, C.J.) (stating that the three judges voting to affirm the district court's decision also "abide by the majority panel opinion"); supra note * (explaining that the half of the en banc court that voted to affirm the district court's decision also adopted the vacated majority panel opinion).

134 Codified at SuP. Jud. CT. Rules 3:08 of the Supreme Judicial Court of Mas- 
requires prior judicial approval of attorney subpoenas. ${ }^{135}$ The federal District Court upheld the validity of PF $15,{ }^{136}$ as did the First Circuit, which, in a 2-1 panel decision, described the rule as "a limited, reasonable response to what appears to be a mounting professional problem."137 On rehearing en banc after vacating the panel decision, the First Circuit divided 3-3, thereby reinstating the panel's affirmance of the district court. ${ }^{138}$

In the Klubock litigation, the principal issue was whether PF 15 conflicts with Federal Rule of Criminal Procedure 17(a), which authorizes the court clerk to issue subpoenas in blank to any party without prior judicial approval, ${ }^{139}$ or with Supreme Court precedent-such as Branzburg and Dionisio-concerning the traditionally unfettered scope of grand jury inquiry. ${ }^{140}$ The government contended (1) that PF 15 is more than a local procedural or ethical rule, and, therefore, the district court did not have the authority to adopt it, and (2) that because Rule 17 does not contemplate prior judicial approval of subpoenas, PF 15 is in conflict with it. ${ }^{141}$ Although the Klubock courts focused on whether PF 15 is a substantive or merely procedural rule, they did not lose sight

sachusetts and incorporated by reference into Local Rule $5(d)(4)(B)$ of the Federal District Court for the District of Massachusetts. PF 15 states that "[i]t is unprofessional conduct for a prosecutor to subpoena an attorney to a grand jury without prior judicial approval in circumstances where the prosecutor seeks to compel the attorney/ witness to provide evidence concerning a person who is represented by the attorney/ witness."

${ }^{135}$ For a more detailed discussion of PF 15 and rules similar to it, see infra text accompanying notes 187-93. See also Gertner, On Trial! A Disciplinary Rule that Limits Attorney Subpoenas, GRIM. JUST., Fall 1986, at 2, 6 (discussing PF 15 litigation).

${ }_{136}$ See Klubock, 639 F. Supp. at 117.

137 Klubock, 832 F.2d at 657.

${ }^{138}$ It is significant that only one of the dissenting judges reached the merits of the district court's power to adopt PF 15. See id. at 668 (Campbell, C.J., dissenting). The other two dissenters questioned the validity of PF 15 solely on the ground that the rule had been adopted, in their view, without sufficient adherence to the procedural requirements of notice and comment. See id. at 671 (Breyer, J., dissenting). The Justice Department has decided not to seek review of this decision in the Supreme Court.

${ }^{139}$ FED. R. CRIM. P. 17(a) provides as follows:

A subpoena shall be issued by the clerk under the seal of the court ....

The clerk shall issue a subpoena, signed and sealed but otherwise in blank to a party requesting it, who shall fill in the blanks before it is served. A subpoena shall be issued by a United States magistrate in a proceeding before him, but it need not be under the seal of the court.

140 See supra text accompanying notes 122-32.

${ }^{141}$ See Klubock, 832 F.2d at 652-56. Even though PF 15 was clearly a federal district court rule (as well as a state rule) by the time the First Circuit considered its validity, the government continued to argue that enforcement of PF 15 by the Commonwealth of Massachusetts against federal prosecutors would violate the supremacy clause. The court found this issue to be moot. Id. at 651; see infra notes 195-96 and accompanying text. 
of the underlying controversy regarding the use of attorney subpoenas. Indeed, none of the Klubock opinions ${ }^{\mathbf{1 4 2}}$ challenge the view that regulation of attorney subpoenas may be needed. Rather, they focus on whether such regulation should be sought in a different manner, such as through national legislation or more rigorous rulemaking procedures. ${ }^{143}$

\section{c. Other Applications of Supervisory Power}

Another direction in which the courts have turned in regulating the use of attorney subpoenas can be seen in those cases in which the courts have made an ad hoc decision not to enforce the subpoena because of the particular circumstances under which it was issued. ${ }^{\mathbf{1 4 4}}$ In such cases, the courts seek to balance the government's need for the evidence sought against the harm that the subpoena may cause to an attorney-client relationship. ${ }^{145}$

One of the most noteworthy examples of that type of case-by-case application of supervisory power is In re Grand Jury Matters (Hodes and Gordon), ${ }^{\mathbf{1 4 6}}$ in which the First Gircuit upheld a district court decision to quash five attorney subpoenas. The district court found that the U.S. Attorney's actions, in issuing grand jury subpoenas to five attorneys who were on the verge of trial in state court, were "without doubt harassing" and had a "chilling effect" on the attorneys' representation of their clients. ${ }^{147}$ Affirming the district court's decision to quash the subpoenas, the First Circuit emphasized the timing of the U.S. Attorney's actions and avoided creating a blanket rule concerning attorney

142 There have been six: the district court opinion by Judge Zobel, $639 \mathrm{~F}$. Supp. 117, 118-26 (D. Mass. 1986); two opinions for the court of appeals by Judge Torruella, 832 F.2d at 650-58; id. at 665-68; two dissenting opinions by Chief Judge Campbell, id. at 658-64; id. at 668-71; and a dissenting opinion by Judge Breyer, id. at $671-75$.

${ }^{143}$ Chief Judge Campbell suggests that such regulation should be implemented at a national level, either by legislation or rulemaking. See 832 F.2d at 661. Judge Breyer's opinion states that such regulation, if adopted locally, must first run the gauntlet of notice and comment prescribed in FED. R. CRIM. P. 57. See 832 F.2d at 671.

${ }^{144}$ See, e.g., In re Grand Jury Investigation (Sturgis), 412 F. Supp. 943, 945-46 (E.D. Pa. 1976) (declining to enforce attorney subpoena with respect to work product, but noting that "[t]he matter at issue can be understood only in light of the unusual nature of the criminal investigation which underlies it").

${ }_{145}$ See In re Terkeltoub, 256 F. Supp. 683, 686 (S.D.N.Y. 1966) ("balancing the claim of need for the testimony against the potential hurt of it" and finding "no overriding necessity for compelling the attorney's testimony at this time").

I46 751 F.2d 13 (1st Cir. 1984).

147 See In re Grand Jury Matters (Hodes and Gordon), 593 F. Supp. 103, 107 (D.N.H.), affd, 751 F.2d 13 (1st Cir. 1984). 
subpoenas. ${ }^{148}$ Indeed, the court intimated that it might permit such subpoenas in the future if they are issued "at a more suitable moment or upon a more substantial showing of immediate urgency and need." 149 Nevertheless, the court reaffirmed the principle that federal courts have the supervisory power to quash subpoenas "even though the subpoenaed materials are not covered by a statutory, constitutional, or common law privilege."150 In doing so, the court expressed a particular concern about the threat that attorney subpoenas pose to the right to counsel. ${ }^{151}$

Courts have also exercised their supervisory power in connection with attorney subpoenas by barring the prosecution from calling the defendant's attorney as a witness unless her "testimony is both necessary and unobtainable from other sources."152 In such cases, as in Hodes and Gordon, courts have struck a balance between the government's stated need for the attorney's testimony and the potential resultant harm to the defendant. ${ }^{153}$ Although analogous types of supervisory power have been used in a wide variety of circumstances to curb prosecutorial abuses ${ }^{154}$ the courts have nevertheless held that their supervisory power over attorney subpoenas is narrow. ${ }^{15 s}$ The courts' su-

148 See Hodes and Gordon, 751 F.2d at 19-20; see also In re Grand Jury Proceedings (Wilson), 760 F.2d 26, 27 (1st Cir. 1985) (noting that timing of the subpoena was an important factor cited by the Hodes and Gordon court).

149 Hodes and Gordon, 751 F.2d at 19-20.

150 Id. at 17-18.

251 See id. at 17 (noting "the importance that the federal Constitution places upon the right to counsel"); $i d$. at 18 (noting that the attorney subpoena "implicates serious policy concerns").

${ }_{182}$ See, e.g., United States v. Crockett, 506 F.2d 759, 760 (5th Cir.) (noting that “[a]s a general rule, a party's attorney should not be called as a witness), cert. denied, 423 U.S. 824 (1975); cf. United States v. Diozzi, 807 F.2d 10, 16 (1st Cir. 1986) (holding that the prosecution failed to justify disqualifying appellants' chosen counsel).

${ }^{163}$ Federal courts exercise an analogous power under FFD. R. Evid. 403 to bar testimony that would be cumulative or otherwise unnecessary. See United States v. King, 827 F.2d 864, 867 (1st Cir. 1987).

${ }_{154}$ See Beale, Reconsidering Supervisory Power in Criminal Cases: Constitutional and Statutory Limits on the Authority of the Federal Courts, 84 Col.um. L. REv. 1433, 1434 (1984) (tracing the origins of federal courts' supervisory power) (n.b.: page numbers 1433 and 1434 are repeated in the cited volume); $c f$. McNabb v. United States, 318 U.S. 332, 341 (1943) (noting that the "Court has, from the very beginning of its history," formulated evidentiary rules to exercise its "supervisory authority over the administration of criminal justice in the federal courts").

15s See In re Grand Jury Subpoena Served Upon Doe, 781 F.2d 238 (2d Cir.) (en banc) (reversing panel decision, reported at 759 F.2d 968 (2d Cir. 1985), that would have required the government, as a precondition to subpoenaing an attorney's testimony on attorney-client matters, to show that the testimony sought was both necessary to the investigation before the grand jury and not reasonably available otherwise), cert. denied, 475 U.S. 1108 (1986); see also In re Grand Jury Proceedings (85 Misc. 140), 791 F.2d 663, 665-66 (8th Cir. 1986) (declining to require a government affidavit showing legitimate need and relevance of the attorney's testimony); In re Klein, 776 
pervisory power, therefore, is not an adequate means of curbing prosecutors' misuse of attorney subpoenas.

\section{B. Ethical Rules}

Until recently, one might have assumed that the ethical rules regulating attorney conduct would make it impossible for prosecutors to obtain information through the use of attorney subpoenas. Attorneys are required, for example, (1) to assert the attorney-client and work-product privileges that pertain to information obtained in the course of representing a client, ${ }^{168}$ and (2) to protect from disclosure information relating to their clients even when that information is not covered by attorney-client or work-product privilege. ${ }^{157}$ In addition, prosecutors are bound by ethical rules which require them (1) to further the interests of justice instead of merely seeking to obtain convictions, ${ }^{\mathbf{1 6 8}}$ and (2) to refrain from taking actions designed to harass an opponent ${ }^{159}$ or to circumvent applicable ethical rules. ${ }^{160}$

In practice, however, these rules do not provide adequate safeguards for the attorney or the client with respect to attorney subpoenas for several reasons. First, the rules governing disclosure of client secrets and confidences permit attorneys to disclose them when "required by

F.2d 628, 634 (7th Cir. 1985) (noting that grand juries and prosecutors, not courts, are the arbiters of how much information a grand jury requires); In re Grand Jury Proceeding (Schofield), 721 F.2d 1221, 1223 (9th Cir. 1983) (refusing to require government preliminary affidavit disclaiming ill intent in case of attorney subpoena); In re Grand Jury Proceedings (Freeman), 708 F.2d 1571, 1575 (11th Cir. 1983) (declining to require government affidavit of need and relevance prior to compelling attorney's testimony); In re Walsh, 623 F.2d 489, 493 (7th Cir.) (refusing "to afford attorneys the right to refuse to appear before grand juries"), cert. denied, 449 U.S. 994 (1980).

${ }_{106}$ See Silbert, supra note 54, at 359; $c f$. Model Code of Professional ReSPONSIBILITY EC 4-4 (1980) (exhorting attorneys to act in a way that "preserves the evidentiary privilege"). But see id. EG 4-2, DR 4-101(C)(2) (noting that an attorney's obligation to her client does not preclude disclosure of information when "required by law").

187 See Model Code of Professional Responsibility DR 4-101 (1980) (broadly defining the scope of the information to be kept confidential by the lawyer); Model Rules of Professional Conduct Rule 1.6 comment [5] (1987).

158 See Model Code of Professional Responsibility EC 7-13 (1980) (prosecutor's "duty is to seek justice, not merely to convict"); id. DR 1-102(A)(5) (a lawyer may not engage in conduct prejudicial to the administration of justice); MODEL RULES of Professional Conduct Rule 3.8 \& comment [1] (1987) (setting forth the prosecutor's special responsibilities as a "minister of justice" instead of merely an advocate); id. Rule 8.4(d) (declaring it to be professional misconduct for a lawyer to engage in conduct prejudicial to the administration of justice).

169 Model Code of Professional Responsibility DR 7-102(A)(1) (1980);

Model Rules of Professional Conduct Rules 3.1, 4.4 (1987).

160 Model Code of Professional Responsibility DR 1-102(A)(2) (1980); Model Rules of Professional Conduct Rule 8.4(a) (1987). 
law or court order."161 While an attorney subpoena, by itself, may not constitute sufficient legal compulsion to permit such disclosure, a court order enforcing the subpoena certainly would. Second, the client may never learn that the attorney has complied with a subpoena because disclosure under court order or other legal compulsion, unlike disclosure of secrets and confidences to which the client consents, does not require the attorney to consult with her client prior to making the disclosure. ${ }^{162}$ Third, although the client generally has the right to intervene in any proceedings in which the attorney may be compelled to disclose otherwise privileged information, ${ }^{\mathbf{1 0 3}}$ a client who is unaware of the attorney subpoena will never, as a practical matter, have the opportunity to exercise that right. ${ }^{164}$

Finally, in a system where there is no routine judicial review of attorney subpoenas, neither the courts nor the disciplinary authorities may learn of the prosecutor's actions, in which case enforcement of the relevant ethical rules is unlikely. The client may be aware of neither the relevant ethical rules nor the disciplinary mechanism through which they are enforced. Both the client and her attorney, moreover, have a powerful incentive not to press disciplinary charges concerning the attorney subpoena (1) because of the deferential manner in which courts generally review a prosecutor's discretionary decisions, ${ }^{165}$ and (2) because the attorney and client are vulnerable to retaliation, from the

181 Model Code of Professional Responsibility DR 4-101(C)(2) (1980); Model Rules of Professional Conduct Rule 1.6 (1987). See Fried, supra note 17, at 497 ("Thus both the Model Code and the Model Rules make the attorney's duties as an officer of the court independent of and always superior to the duties to his or her client."). It is worth noting that such disclosure is not permitted under the proposed American Lawyer's Code of Conduct, which rejects the "officer of the court" rationale insofar as it is contrary to zealous advocacy. See id. at $497 \&$ nn. 301-02.

162 Compare Model Code of Professional Responsibility DR 4-101(C)(1) (1980) (a lawyer may reveal confidences with the consent of the client(s) "but only after a full disclosure to them") with id. DR 4-101(C)(2) (a lawyer may reveal confidences when "required by law or court order").

183 See generally Glanzer \& Taskier, supra note 17, at 1075-76 (noting that in almost all circuits, the right of the client to intervene is upheld).

164 Thus, several of the proposed solutions to the attorney subpoena problem require notice to the client and an opportunity for the client to be heard before the subpoena can be served or enforced. See, e.g., NNRC proposal, $\S 2$ (Appendix B); ABA proposal (Appendix C).

${ }^{165}$ See, e.g., Wayte v. United States, 470 U.S. 598, 607 (1985) (noting the decision of whether or not to prosecute is poorly suited for judicial review); United States v. Moran, 759 F.2d 777, 783 (9th Gir. 1985) (granting broad discretion to the prosecutor regarding the timing of indictments), cert. denied, 474 U.S. 1102 (1986); United States v. Williams, 738 F.2d 172, 175 n.2 (7th Cir. 1984) (allowing prosecutor broad discretion to set priority on cases being handled); see also Fifteenth Annual Review of Criminal Procedure: United States Supreme Court and Courts of Appeals 1984-1985, 74 GEO. L.J. 621, 621 (1986). 
prosecutor, in various forms including further required appearances before the grand jury. ${ }^{168}$

Notwithstanding these deficiencies, adoption of ethical rules to curb the use of attorney subpoenas remains an important means of regulating the prosecutor's conduct. A civil action against the prosecutor is almost certain to fail because of the prosecutor's nearly absolute immunity from civil liability. ${ }^{167}$ Thus, enforcement of the applicable disciplinary rules provides one of the few mechanisms available to ensure that prosecutors live up to their professional duties. ${ }^{168}$

Some jurisdictions-such as the state courts of Massachusetts, Tennessee, and Virginia and the Federal District Court of Massachusetts-have adopted ethical rules specifically aimed at curbing the misuse of attorney subpoenas. These rules, which are discussed more fully below, ${ }^{189}$ require prior judicial approval of subpoenas that seek information concerning the attorney's client.

\section{United States Justice Department Guidelines}

In July 1985, the United States Department of Justice responded to the growing concern of attorneys and bar associations about the use of attorney subpoenas by issuing comprehensive attorney subpoena guidelines. ${ }^{170}$ While the Guidelines represent a candid acknowledgment of the problems created by the Department of Justice's use of attorney subpoenas, they are for the most part an ineffective means of remedying those problems. Indeed, the Guidelines seem to institutionalize the practice of subpoenaing attorneys.

${ }^{106}$ This possibility did not escape the Klubock court, which noted the potential for abuse in the use of attorney subpoenas, a result of the natural tendencies of the adversarial process. See United States v. Klubock, 832 F.2d 649, 654 (1st Cir. 1987), vacated, United States v. Klubock, No. 86-1413 (1st Cir. May 1, 1987) (order granting rehearing en banc, which withdrew the panel's opinion and vacated its judgment); see also United States v. Klubock, 832 F.2d 664, 665 (en banc) (Torruella, C.J.) (stating that the three judges voting to affirm the district court's decision also "abide by the majority panel opinion"); supra note * (explaining that the half of the en banc court that voted to affirm the district court's decision also adopted the vacated majority panel opinion).

${ }_{187}$ See, e.g., Imbler v. Pachtman, 424 U.S. 409, 430-31 (1976) (noting the absolute immunity granted to prosecutors). But see Taylor v. Kavanagh, 640 F.2d 450, 45153 (2d Cir. 1981) (describing a method of differentiating "quasi-judicial" acts-for which the prosecutor receives absolute immunity - from "investigative" acts-for which the prosecutor receives only qualified immunity).

168 See Imbler, 424 U.S. at 429.

169 See infra notes 183-97 and accompanying text.

170 See J. Backman, supra note 17, at 14-15. The text of the Justice Department guidelines, EXecutive OfFice for the United States AtTorneys, DePartment of Justice, United States AtToRneys' Manual § 9-2.161(a) (1985) [hereinafter GuIDELINES], appears in Appendix A of this Article. 
Noting that the use of attorney subpoenas involves "potential adverse effects upon the attorney-client relationship,"171 the Guidelines call for the Department of Justice to "exercise close control over the issuance of such subpoenas,"172 attempting in each case to "strike the proper balance between the public's interest in the fair administration of justice and effective law enforcement and [the] individual's right to the effective assistance of counsel."173 The Guidelines acknowledge, in particular, "the risk that the attorney will be disqualified from the representation of the client as a result of having to testify against the client."174

The Guidelines contain both procedural and substantive provisions. The procedural provision requires that all attorney subpoenas receive prior approval from the Assistant Attorney General of the Criminal Division of the Department of Justice. ${ }^{175}$ Such approval appears to be readily given. ${ }^{176}$

The substantive provisions of the Guidelines call for a five-step analysis of the subpoena request by the Department of Justice. First, the subpoena must be "reasonably needed" for the successful completion of a warranted criminal investigation or prosecution or civil litigation matter. Second, the Department must have exhausted the alternative means of obtaining the information sought. Third, the need for the subpoena must outweigh the risk of damage to the attorney-client relationship, including the risk that the attorney will be disqualified from representing her client because of the subpoena. Fourth, the subpoena must be narrowly tailored as to subject matter and the time period covered. Finally, the information sought cannot be privileged. ${ }^{177}$

The Guidelines represent a laudable attempt to regulate the Department Of Justice's use of attorney subpoenas. ${ }^{178}$ They are, however,

171 GuIdelines, supra note $170, \S 9-2.161(\mathrm{a})(\mathrm{E})(4)$.

172 Id. $\S 9-2.161(\mathrm{a})$.

173 Id. \& 9-2.161(a)(A).

174 Id. $\$ 9-2.161(\mathrm{a})(\mathrm{E})(4)$.

175 See id. \& 9-2.161(a)(D).

${ }_{178}$ During an eight-month period from March through October 1987 (for which this information was available), Department officials rejected only ten requests for attorney subpoenas - i.e., slightly more than one per month. Oral report by Mark Robinson, special counsel to the Assistant Attorney General for the Criminal Division, to Laurie Robinson, Director, ABA Criminal Justice Section, on October 30, 1987. Yet the Department has approved, on the average, 33 attorney subpoenas each month during the first year that the guidelines were in effect, according to their own statistics. See Letter of December 12, 1986, supra note 19 (242 subpoenas from March 1, 1986 to July 31, 1986); Letter of May 19, 1986, supra note 19 (169 subpoenas from July 18, 1985 to February 18, 1986).

${ }_{177}$ See GuIDELINES, supra note $170, \S 9-2.161(\mathrm{a})(\mathrm{F})(2)-(6)$.

178 Skeptics might wonder whether the Guidelines serve more as effort to deflect or moderate criticism of the Department's use of attorney subpoenas than as a limit on 
an inadequate solution to the attorney subpoena problem for a number of reasons. First and foremost, the Guidelines are completely unenforceable. The Department of Justice was not shy about this important feature of the Guidelines, which is clearly stated:

These guidelines ... are set forth solely for the purpose of internal Department of Justice guidance. They are not intended to, do not, and may not be relied upon to create any rights, substantive or procedural, enforceable at law by any party in any matter, civil or criminal, nor do they place any limitations on otherwise lawful investigative or litigative prerogatives of the Department of Justice. ${ }^{179}$

Moreover, even without this disclaimer, the unenforceability of a federal agency's internal guidelines is well established in case law. ${ }^{\mathbf{1 8 0}}$ Thus, the critical balancing of reasonable need versus harm to the attorney-client relationship is, in effect, left under the unilateral control of the prosecution, which stands to benefit from its decision.

Second, there is no method for monitoring the implementation of the Guidelines because they contain no disclosure requirement. Although the Department of Justice has released its own statistics concerning its use of attorney subpoenas, neither the bar, the courts, nor the Department itself can be certain that those statistics tell the full story. ${ }^{181}$

Third, because the Guidelines require prosecutors to make a "reasonable attempt" to pursue alternative sources of information before using a subpoena only if unsuccessful attempts would not "impair the ability to obtain such information from [the] attorney,"182 there will likely be many cases in which the effort to look elsewhere will not be made, since such efforts might come to the attorney's attention and thus, in the prosecutor's view, "impair" her ability to get the information from the attorney.

their use.

179 GuIDELINES, supra note 170, § 9-2.161(a) (emphasis added).

180 See United States v. Caceres, 440 U.S. 741, 755-56 (1979) (evidence acquired in violation of Internal Revenue Service electronic surveillance regulations need not be excluded); $c f$. Schweiker v. Hansen, 450 U.S. 785 (1981) (failure of Social Security Administration employee to follow Claims Manual instructions in advising applicant does not entitle applicant to retroactive benefits).

IBI Compare, for example, the Department of Justice's admission that an average of 50 to 100 attorney subpoenas were issued each year during the last four years (19831986) in the District of Massachusetts alone, see Klubock, 832 F.2d at 658, with statistics released by the Department of Justice in 1986, showing that 411 attorney subpoenas had been issued nationwide. See supra note 19 and accompanying text; supra note 176.

182 GuIdelines, supra note $170, \S 9-2.161(\mathrm{a})(\mathrm{B})-(\mathrm{C})$. 
Finally, because the Guidelines distinguish between privileged and nonprivileged information, the Department can take advantage of the overly broad exceptions to the attorney-client and work-product privileges: the crime/fraud exception and the doctrines pertaining to client identity and fee information.

\section{The Bar Response}

The organized bar has responded to the mounting concern over the use of attorney subpoenas with rare unanimity. A number of state and national bar associations, including the American Bar Association, have adopted attorney subpoena proposals, some of which either have been adopted or are presently under consideration by the courts and legislatures.

The first such proposal, which was introduced by the Massachusetts Bar Association, called for prior judicial review of attorney subpoenas at an ex parte hearing in which the prosecution was required to establish several factors: that the information sought was nonprivileged, relevant, and unavailable from other sources; that compliance with the subpoena would not be unreasonable or oppressive; and that the subpoena was not sought for purposes of harassment. ${ }^{183}$ This proposal was adopted in part by the Massachusetts Supreme Judicial Court as an ethical rule ("PF 15"), which required that the prosecutor obtain prior judicial approval of attorney subpoenas. ${ }^{184}$ The MBA proposal was also adopted, with minor changes, by the American Bar Association in

${ }^{183}$ The MBA proposal states, in pertinent part:

RESOLVED, that it is the position of the MBA that it should be considered to be unprofessional conduct and inimical to the administration of justice for a prosecutor or other government attorney to subpoena an attorney to the grand jury, or to any state or federal administrative body with a similar function, without prior judicial approval in circumstances where the prosecutor or such other government attorney seeks to compel the attorney/witness to provide evidence concerning a person who at the time is represented by the attorney/witness. "Prior judicial approval" in such cases should be withheld unless, after a hearing conducted with due regard for the need for the secrecy of grand jury proceedings, the court finds (1) the information sought is not protected from disclosure by the attorneyclient privilege or the work-product doctrine; (2) the evidence sought is relevant to an investigation within the jurisdiction of the grand jury (3) compliance with the subpoena would not be unreasonable or oppressive (4) the purpose of the subpoena is not primarily to harass the attorney/ witness or his or her client; and (5) there is no other feasible alternative to obtain the information sought.

Mass. Bar Ass'n, Criminal Justice Section, Proposed Resolutions 421 (1985).

184 See Mass. Supreme Judicial Court Rule 3:08 (PF 15) (1987). For discussion of PF 15 and the text of the rule, see supra notes 133-43 and accompanying text. 
February, 1986, in a resolution that called for implementation of such proposals throughout the United States. ${ }^{185}$ In February 1988, the ABA adopted a broader version of this proposal, introducing a number of changes, such as an adversary proceeding. ${ }^{\mathbf{1 8 6}}$

In several other states, attorney subpoena proposals have been adopted as ethical rules that require prosecutors to seek prior judicial approval before issuing the subpoena. In Massachusetts, PF 15 has been adopted by both the state and federal courts. ${ }^{187}$ The Supreme Courts in both Tennessee ${ }^{188}$ and Virginia ${ }^{189}$ adopted rules similar to PF 15 in 1987; those rules have not yet been adopted by the federal courts in those states. The Tennessee rule, codified as DR 7-103(c), is somewhat broader than PF 15 because it applies to "any state and federal administrative body" with a function similar to a grand jury, rather than only to grand juries. ${ }^{180}$ The Virginia ethical rule, codified as DR 8-102(A) of the Rules for the Integration of the Virginia Bar, is also somewhat broader than PF 15 in two respects: it covers past as well as present representation, and it extends beyond grand jury proceedings to any criminal proceeding. ${ }^{191}$ The Virginia Supreme Court has also adopted a procedural rule, broader in scope than PF 15, which requires notice to the attorney. ${ }^{192}$.In addition, six other states and the

185 The ABA Resolution, Appendix C, omits the "not unreasonable or oppressive" element of the MBA proposal. In turn, it adds that findings made pursuant to the hearing will have no effect on subsequent proceedings concerning the subpoena.

${ }^{186}$ The ABA's 1988 Resolution calls for an adversary, not ex parte, proceeding; covers both past and present representation; requires a showing that the information sought is not only relevant but "essential to the successful completion of an ongoing investigation or prosecution"; requires that the information sought must be listed with particularity and must be reasonably limited by subject matter and period of time covered; and requires a showing that the prosecutor has exhausted all non-attorney sources of the information sought. The text of the ABA's 1988 Resolution is reproduced in Appendix D.

${ }_{187}$ See supra text accompanying note 184 (noting the Massachusetts Supreme Judicial Court's adoption of PF 15); supra notes $133-43$ and accompanying text.

188 TrNn. Cr. R. DR 7-103 (1987).

${ }^{189}$ Supreme Court Rule Changes, 35 VA. B. NEws 23 (1987) [hereinafter Supreme Court].

190 See TENn. CT. R. DR 7-103 (1987).

191 See Supreme Court, supra note 189 , at 23. as follows:

${ }^{192}$ See id. at 22-23. Virginia Supreme Court Rule 3A:12 states in pertinent part

No subpoena or subpoena duces tecum shall be issued in any criminal case or proceeding, including any proceeding before any grand jury, which subpoena or subpoena duces tecum is (i) directed to a member of the bar of this Commonwealth or any other jurisdiction, and (ii) compels production or testimony concerning any present or former client of the member of the bar, unless the subpoena request has been approved in all specifics, in advance, by a judge of the circuit court wherein the subpoena is requested after reasonable notice to the attorney who is the subject of the proposed 


\section{District of Columbia have considered adopting attorney subpoena rules. $^{193}$}

subpoena. The proceedings for approval may be conducted in camera, in the judge's discretion, and the judge may seal such proceedings. Such subpoena request shall be made by the commonwealth's attorney for the jurisdiction involved, either on motion of the commonwealth's attorney or upon request to the commonwealth's attorney by the foreman of any grand jury.

Id.

${ }^{193}$ The Rules Committee of the Rhode Island Supreme Court has recommended to that Court adoption of an attorney subpoena rule that closely approximates PF 15. The Court has not yet acted on that recommendation. Rules Committee, R.I. S.Ct., Proposed Rules of Professional Responsibility R. 3.8 (1987).

The Board of Governors of the District of Columbia Bar has adopted an attorneysubpoena rule that is broader than PF 15. The D.C. Bar proposal covers past and present attorney-client relationships and, with respect to the client, includes any "person or entity" (emphasis omitted). Proposed Rule 3.8 (j). The proposal is now under consideration by the District of Columbia Court of Appeals. Bd. of Governors, D.C. Bars, Proposed Rules of Professional Conduct and Related Comments (Nov. 19, 1986).

Both Houses of the Illinois legislature passed an attorney-subpoena proposal, which had been recommended by the Illinois State Bar Association but was vetoed by Governor Thompson. The Illinois proposal, which is expected to be resubmitted in 1988, Letter from Mary McClain, Assistant Director, Legislative Affairs, Illinois State Bar Association to David Hoffman (Dec. 2, 1987), is essentially identical to the February 1986 ABA resolution. H.B. 192, 85th Gen. Assembly, Ill. (1987-88) (seeking to amend the Act in effect since 1963). The Illinois State Bar Association has also submitted a proposal requiring prior judicial approval of attorney subpoenas to the Illinois Supreme Court, where it is now under consideration. See Petition to Amend Proposed Rule 7-103 of Iilinois Code of Professional Responsibility (No. MR4816) (Filed Feb. 11, 1988).

The Board of Governors of the Florida Bar adopted an attorney subpoena rule in April 1987 and submitted it to the Florida Supreme Court for approval. The Court recently rejected the proposal, that closely approximated PF 15 . The Florida Bar Re: Amendment to the Rules Regulating the Florida Bar, No. 70366 (Fla., Oct. 22, 1987) (WESTLAW, State Library, Fla. File) (discussing rejection of an added paragraph to rule $4-3.8$ ).

The New Hampshire Bar Association submitted a proposal to the state Supreme Court's Rules Committee in June 1986 that closely approximated PF 15. The Rules Committee adopted instead a rule which would make it unprofessional conduct for a prosecutor to "issue or obtain the issuance of a subpoena without good cause." The official comment on this rule notes that it "reflects the general obligation of a lawyer . . . to respect the rights of third persons." This proposal is still under consideration by the New Hampshire Supreme Court. N.H. Bar Ass'n, Proposed Amendment of Rule 3.8 of the N.H. Rules of Professional Conduct (June 1986).

The House of Delegates of the New York State Bar Association unanimously adopted, in January 1986, a broad attorney-subpoena proposal similar to the resolution adopted by the American Bar Association. The New York proposal was considered by the Jones Committee, which was established by the New York State Bar Association to examine the proposed Code of Professional Responsibility. The Jones Committee declined to adopt the proposal but instead invited comment on it. In June 1987, the House of Delegates adopted a substitute proposal that was similar to PF 15 but with two exceptions: the substitute proposal covers both present and past representation and it requires notice to the attorney and client. This proposal was passed by an overwhelming majority and submitted to the various Appellate Divisions of the State of New York for adoption. No action has yet been taken on the proposal. House of Delegates, N.Y. Bar Ass'n, Proposed Rule of Professional Responsibility DR 7-103(c) 
These rules and proposals are an important step in the direction of regulating the use of attorney subpoenas. However, they do not provide adequate client protection for several reasons. First, it is unclear whether a violation of these rules can be invoked by the attorney or the client as a bar to enforcement of the subpoena. In Klubock, the First Circuit emphatically rejected such a use for PF $15 .{ }^{184}$ If an attorney subpoena rule can only be enforced by means of disciplinary proceedings, which may occur, if at all, long after the attorney's appearance before the grand jury has been compelled, the very harm which the rule seeks to prevent will have already occurred.

Another concern is that unless the federal district courts adopt the same rules as the states in which they sit, there may be a question as to whether federal prosecutors will be bound by the state rule. Although this objection to the enforcement of PF 15 was rejected by the district court in Klubock, ${ }^{195}$ the Court of Appeals declined to rule on the issue. $^{196}$

(June, 1987).

In Pennsylvania the Disciplinary Board of the Supreme Court of Pennsylvania is considering a proposal somewhat broader than PF 15 in that it would apply to grand juries or "other tribunal[s] investigating criminal activity" and covers both present and past representation. Proposed Rule 3.10, Pennsylvania Bulletin, Volume 18, No. 1, at 10 (Jan. 2, 1988).

194 See United States v. Klubock, 832 F.2d 649, 657 (1st Cir.) (stating that "[a]ttorneys are not, by virtue of such status, exempt from answering to subpoenas when properly served, including even when compliance has not been made with provisions such as PF 15."), vacated, United States v. Klubock, No. 86-1413 (1st Cir. May 1,1987 ) (order granting rehearing en banc, which withdrew the panel's opinion and vacated its judgment); see also United States v. Klubock, 832 F.2d 664, 665 (1st Cir. 1987) (en banc) (stating that the three judges voting to affirm the district court's decision also "abide by the majority panel opinion"); supra note * (explaining that the half of the en banc court that voted to affirm the district court's decision also adopted the vacated majority panel opinion). Such a limitation would, presumably, not apply to a procedural rule, such as Virginia's Rule $3 \Lambda: 12$.

185639 F. Supp. 117, 125-26 (D. Mass. 1986).

${ }^{198}$ Klubock, 832 F.2d at 651-52. During the Klubock litigation, PF 15 was explicitly adopted as a local rule by the federal district court for the District of Massachusetts while the Justice Department's action to enjoin enforcement of PF 15 against federal prosecutors was pending before the First Circuit. Until that explicit adoption occurred, the Department of Justice had advanced two major arguments.

First, the Department of Justice argued that PF 15, if incorporated by the district court's local rules, was inconsistent with Federal Rule of Criminal Procedure 17 and therefore invalidated by Federal Rule of Criminal Procedure 57, which permits the promulgation of local rules "not inconsistent with" the Federal Rules of Criminal Procedure. Klubock, 639 F. Supp. at 121. The district court held, however, that Federal Rule of Criminal Procedure 17's criteria for the issuance of subpoenas were not inconsistent with PF 15's requirement of judicial approval prior to service. Id. at 122 .

Second, the Department of Justice argued that, if PF 15 was not incorporated by the district court's local rules, "PF 15 offends the Supremacy Clause because it interferes with [the duties of] federal officers . . .."Id. at 125. The district court found no conflict between federal and state law and rejected this argument, id. at 126, explicitly 
Likewise, several of the state rules and proposals require only ex parte proceedings for prior judicial approval of attorney subpoenas. In those states, where neither the attorney nor the client has an opportunity to be heard, the attorney may be forced to appear before the grand jury and assert behind closed doors whatever privileges may be available. Lack of notice to the client may create a situation in which the attorney fails to assert relevant privileges. ${ }^{197}$

Finally, while there is considerable value in the experience that states may acquire in their role as laboratories, the attorney subpoena problem is national in scope and in significance. The solution, ultimately, should be national as well.

\section{Proposals for the Regulation of Attorney Subpoenas}

\section{A. The Policies at Stake}

Assessment of the attorney subpoena problem requires some initial consideration of the unique and important interests at stake. The roles of the attorney and the attorney-client relationship are, of course, central to our adversary system. ${ }^{188}$ At the same time, one cannot gainsay the importance of the job entrusted to prosecutors and the grand jury-namely, ferreting out crime. In balancing these two sets of interests, it is obvious that we cannot afford to sacrifice wholly one set for the other. ${ }^{199}$

reserving the issue of whether the local rules of the district court had adopted PF 15. Id. at 121. The supremacy clause argument was considered moot by the Court of Appeals and so never decided at that level. Klubock, 832 F.2d at 651-52.

197 Although the attorney is duty bound to assert such privileges, it appears that attorneys are ignoring this obligation on a fairly regular basis. Interestingly, the Department of Justice has stated that it would not object to a rule that required a subpoenaed attorney to appear before a judge and verify that she had discussed the subpoena with her client. See Reply Brief of Department of Justice at 20 n.15 United States v. Klubock, 86-1413 (1st Cir. 1987) (Brief filed on September 2, 1986) (noting that the Justice Department "would have no quarrel with such a rule pursuant to the court's supervisory power over the grand jury, subpoenas, or attorney conduct").

${ }_{198}$ See Hickman v. Taylor, 329 U.S. 495, 515 (1947) (Jackson, J., concurring) ("the lawyer and the law office are indispensable parts of our administration of justice" (emphasis added); United States v. Hodge and Zweig, 548 F.2d 1347, 1355 (9th Cir. 1977) (stating that the "attorney-client privilege is central to the legal system and the adversary process"); In re Terkeltoub, 256 F. Supp. 683, 684 (S.D.N.Y. 1966) (discussing the importance of the attorney-client privilege to the client, the interests of the community, and the welfare of the legal system).

${ }^{199}$ Recent experience has required more aggressive prosecution of society's fight against the mounting evils of crime. We commend both vigorous prosecution and all legitimate means in aid of this laudable task. This, however, does not mean that society can afford a 'no holds barred' approach to law enforcement lest the 'solution' engender faults of an equally serious nature. 
1. The Role of the Attorney and the Attorney-Glient Relationship

The centrality of the attorney-client relationship in our criminal justice and adversary systems derives from both constitutional and common law sources. As the oldest common law privilege, the attorneyclient privilege predates our Revolution ${ }^{200}$ and provides one of the basic foundations of our judicial system. The right to counsel is, of course, enshrined in the sixth amendment and in nearly every state constitution, as well as in the jurisprudence of constitutional due process under the fifth and fourteenth amendments. ${ }^{201}$

Although the importance of the attorney-client relationship finds its expression in particular forms - such as ethical rules protecting the client's secrets and confidences, constitutional doctrines concerning the right to effective assistance of counsel, common law attorney-client privilege, and, more recently, attorney work-product privilege - the whole amounts to something greater than its parts. In other words, the rights associated with the attorney-client relationship are not simply an important collection of separate, legally protected interests which our system recognizes - a set of tubs, as it were, each sitting on its own bottom. Rather, these rights derive their significance and justification to some degree from each other and from the fact that, together, they form one of the cornerstones on which our adversary system has been built. The recent efforts to chip away at the legal principles on which the attorney-client relationship depends - as in the area of attorney-client privilege, for example - thus erode one of the basic components of our legal system.

The attorney-client relationship is even more vital today than in the past. Our laws and our legal system have grown so increasingly complex that "the individual lack[s] the requisite skill to handle his or her legal affairs." ${ }^{202}$ The nonlawyer who enters the bewildering thicket of laws presently on the books in the United States without counsel clearly does so at her peril.

Klubock, 832 F.2d at 658.

200 See 8 J. Wigmore, supra note $49, \S 2290$ (noting that attorney-client privilege was considered "unquestioned" as long ago as the sixteenth century).

201 See C. Wolfram, Modern Legal Ethics 791-94 (1986) (reviewing constitutional bases for the right to counsel). The right to counsel is guaranteed by state constitutional provisions in every state except Virginia, where the right to counsel is established by statute. VA. CoDE ANN. § 19.2-157 (1983).

${ }_{202}$ Rosenfeld, supra note 103, at 512; see Upjohn Co. v. United States; 449 U.S. 383, 392-93 (1981) (discussing need for corporations to be able to consult counsel in order to comply with the law); Potashnik v. Port City Constr. Co., 609 F.2d 1101, 1118-19 (5th Cir. 1980) (citing Geders v. United States, 425 U.S. 80, 88 (1976) and stressing need for criminal defendant to be able to communicate with counsel in order to understand trial proceedings). 
Further, this century has witnessed a virtual explosion of federal and state regulatory provisions which establish criminal penalties. ${ }^{203}$ Some of these statutes, such as RICO, ${ }^{204}$ criminalize conduct which as isolated behavior would be lawful. ${ }^{205}$ The proliferation of criminal laws in formerly white collar enclaves ${ }^{206}$ creates an even greater need for legal representation, since the individual's liberty, as well as her property, are in jeopardy.

Technological and legal developments have also greatly increased the power of the government to investigate and prosecute individuals. ${ }^{207}$ In this new legal climate, an unrepresented criminal defendant or investigation target is particularly helpless.

These developments underscore some of the reasons why our society places such a high value on the fundamental right to the assistance of an attorney, including the right to conduct the attorney-client relationship in a confidential manner. Among the most important of those reasons is society's goal of conforming its citizens' conduct to the law. Because of the increasing complexity of the law, individuals, corporations, and other entities more frequently need to consult and confide in attorneys in order to determine whether their conduct is lawful. ${ }^{208}$ Lawyers thus play a vital role in translating the law into a vernacular that their clients understand.

The attorney-client relationship also facilitates the truth-finding process that our courts and other dispute-resolution institutions perform. Two of the premises of our adversary system are (1) that the truth-finding process will be more reliable if each side advocates its position with zeal, ${ }^{209}$ and (2) that an attorney will be better able to advocate her client's case if she has the fullest opportunity to assemble

${ }^{203}$ See generally Fried, supra note 17, at 471 (noting criminal penalties for violation of the Sherman Act, Securities Act of 1933, Securities and Exchange Act of 1934, various tax laws, environmental laws, and laws designed to punish organized crime, such as the Racketeer Influenced and Corrupt Organizations Act ("RICO")).

20418 U.S.C. \$\$ 1961-1968 (1982 \& Supp. IV 1986).

${ }^{205}$ See Fried, supra note 17, at 471-72.

${ }^{208}$ One commentator notes, for example, the existence of more than one hundred federal statutes prohibiting false statements to the Government. Id. at 477.

${ }^{207}$ See Rosenfeld, supra note 103, at 512; see, e.g., California v. Ciraolo, 476 U.S. 207, 215 (1986) (permitting police to make warrantless aerial observations by plane); 18 U.S.C. $\$ 2516$ (1982 \& Supp. IV 1986) (granting authorization for interception of wire or oral communication).

208 See Upjohn Co. v. United States, 449 U.S. 383, $392-93$ (1981) (noting that compliance with "vast and complicated array of regulatory legislation . . . is hardly an instinctive matter" (citations omitted)).

200 See C. WolfRaM, supra note 201, at 581-82 ("[T]he best method of resolving disputes is single-minded representation by client-centered advocates who, in their zeal to assist their clients, are motivated to discover facts and elaborately research and argue the law."). 
the relevant facts about her client without fear that she will be forced to disclose information potentially harmful to the client. ${ }^{210}$

In addition, we rely on the attorney's advocacy on behalf of the client to vindicate the client's rights. ${ }^{211}$ In a legal system such as ours, where the norms are defined in terms of "rights" and "duties" and where the legitimacy of the system depends in large measure on the extent to which individuals' fundamental rights are given equal consideration, it is essential that each individual have a loyal advocate who can work independently of any control by the individual's opponent. ${ }^{212}$

Finally, there are non-instrumental reasons for the special importance we ascribe to the attorney-client relationship - namely, the individual's interest in privacy, dignity, autonomy, and protection. ${ }^{213}$ In this respect, the attorney's relationship with the client is similar to other important privileged relationships which our legal system protects from intrusion and interference, such as those between husband and wife, priest and penitent, and psychiatrist and patient. The client, who may regard her attorney as a trusted ally or friend, certainly expects that she can speak to the attorney with candor and may value that relationship as highly as those which we ordinarily regard as entitled to a guarantee of complete confidentiality. ${ }^{214}$

\section{The Role of the Grand Jury}

Although grand juries are not the only forum in which the attorney can be compelled to testify, the broad powers of the grand jury and the secrecy of its proceedings make its unique role in the attorney subpoena controversy worthy of special attention. Like the attorney-client privilege, the grand jury has its roots in the legal tradition that we inherited from England. ${ }^{215}$ The framers of the Constitution and the Bill of Rights considered the grand jury to be such an important safeguard from oppression that they included it in the fifth amendment as a

210 See Trammel v. United States, 445 U.S. 40, 51 (1980) (noting that the "lawyer-client privilege rests on the need for the advocate and counselor to know all that relates to the client's reasons for seeking representation if the professional mission is to be carried out"); Fisher v. United States, 425 U.S. 391, 403 (1976) ("The purpose of the privilege is to encourage clients to make full disclosure to their attorneys.").

211 See Rosenfeld, supra note 103, at 505-06.

212 See supra note 101 and accompanying text.

213 For a useful discussion of the utilitarian and non-utilitarian justifications for privilege, see Developments in the Law, supra note 65, at 1501-07.

${ }_{214}$ See generally Fried, The Lawyer as Friend: The Moral Foundations of the Lawyer-Client Relation, 85 YALE L.J. 1060, 1071 (1976) (analogizing a lawyer to a friend in that she acts not in her own, but in her client's interest). jury).

${ }^{216}$ See $1 \mathrm{~W}$. LaFave, Criminal. Procedure $§ 8.2$ (discussing history of grand 
governmental body designed to be independent of both the prosecutor and the courts. ${ }^{216}$ The grand jury's dual purpose was "to discover and present for trial persons suspected of criminal wrongdoing and [to protect] citizens against arbitrary and oppressive governmental action."217

In recent years, however, both the grand jury's independence and its role as a "protector" of individuals have been questioned more closely. Critics have pointed out that grand juries seldom act independently of prosecutors. As the ABA noted in its 1982 report on the grand jury, "[w]hile the grand jury was enshrined in our Constitution because of its reputed ability to protect the innocent from unfounded prosecution, few scholars or practitioners takes [sic] its accusatorial function seriously today."218 Thus, as a Justice Department official conceded, "the grand jury does not operate to protect the individual to any substantial degree."219

Today, no longer an independent institution, the grand jury serves as a powerful adjunct to prosecutors' law enforcement efforts within their respective districts. The grand jury is useful to the government because, unlike the prosecutor, the grand jury can compel the appearance of witnesses and require them to testify (by giving them immunity if necessary). Witnesses resisting the grand jury's compulsion may be held in contempt and imprisoned. ${ }^{220}$ In addition, grand jury proceed-

${ }^{216}$ United States v. Chanen, 549 F.2d 1306, 1312 (9th Cir.) (The grand jury is an independent body that is "not relegated by the Constitution to a position within any of the three branches of the government."), cert. denied, 434 U.S. 825 (1977).

217 United States v. Galandra, 414 U.S. 338, 343 (1974).

218 ABA, Grand Jury Policy and Model Act (1977-1982) 20 (1982) [hereinafter ABA Report II]. The ABA Report cites statistics showing that in one year federal grand juries returned approximately 23,000 indictments and reported only 123 no true bills. See id. at 27 n.5; see also Emerson, Grand Jury Reform: A Review of Key Issues 21 (U.S. Department of Justice, National Institute of Justice, January, 1983) (reporting study showing that grand jurors discussed only $20 \%$ of the cases before voting on them, and returned $95 \%$ of the indictments sought by the prosecutor); Campbell, Eliminate the Grand Jury, 64 J. CRIM. L. \& Criminology 174, 174 (1973) ("Today, the grand jury is the total captive of the prosecutor who, if he is candid, will concede that he can indict anybody, at any time, for almost anything, before any grand jury.'); Zwerling, Federal Grand Juries v. Attorney Independence and the Attorney-Client Privilege, 27 Hastings L.J. 1263, 1268 (1976) (noting "evolution of the grand jury from a more or less independent institution to an institution completely dominated by the prosecutor"); $c f$. T. WOLFE, THE BonfIRE of THE VANITIES 603 (1987) (quoting New York Court of Appeals Ghief Judge Wachtler as saying that "a grand jury would 'indict a ham sandwich,' if that's what [the prosecutor] wanted"). Significantly, many states have eliminated the grand jury from their own criminal justice systems. See S. Beale \& W. Bryson, Grand Jury Law and Practice, $\S \S 2.03,2.04$ (1986).

21120 Cong. Rec. 38,292-94 (1974) (letter from Assistant Attorney General W. Vincent Rakestraw to Chairman of the House Judiciary Committee, Representative Peter W. Rodino Jr.).

${ }^{220}$ See W. LAFAve, supra note $215, \S 8.3$ ("The grand jury may utilize the subpoena duces tecum to obtain tangible evidence and the subpoena ad testificandum to 
ings are not limited by the strictures of "relevance" or the ordinary exclusionary rules that apply at trial. ${ }^{221}$ A grand jury can cast its subpoenas far and wide and is generally entitled to "every man's evidence." ${ }^{222}$ In general, the witness has no right to demand any showing of "cause" for issuance of the subpoena. ${ }^{223}$ The secrecy with which grand jury proceedings are conducted ${ }^{224}$ also contributes to their coercive atmosphere. ${ }^{225}$ This particular combination of extraordinary powers, secrecy, and minimal limitations on the evidence that it may hear has resulted, according to the $\mathrm{ABA}$, in "a gross imbalance . . . between the awesome powers of the government acting through the . . grand jury, on the one hand and the limited rights of the grand jury witness, on the other." 226

\section{B. A Balancing Act: \\ Four Proposals for Regulation of Attorney Subpoenas}

An appropriate balance must be struck between the two interests arrayed against one another in the attorney subpoena setting. Indeed, on one fundamental point, both the Justice Department and its critics agree: attorney subpoenas are not to be resorted to casually; there must be a concrete reason, of sufficient weight to justify the likely disruption of the attorney's relationship with her client. This much is implicit in the Department's Guidelines. ${ }^{227}$ There are, of course, differences of opinion both on what constitutes a satisfactory reason for issuing the subpoena and on who should decide that question. There is no real

obtain testimony. Both subpoenas are supported by the court's authority to hold in contempt any person who willfully refuses, without legal justification, to comply with a subpoena's directive." (footnote omitted)).

221 See Note, supra note 51 , at 570 \& n.186.

222 Branzburg v. Hayes, 408 U.S. 665, 688 (1972); see United States v. Nixon, 418 U.S. 683, 709 (1974); United States v. Dionisio, 410 U.S. 1, 9 (1972).

${ }^{\mathbf{2 2 3}}$ But see supra note 121 and accompanying text.(discussing requirement of preliminary showing for enforcement of grand jury subpoenas in Third and Tenth Circuits).

${ }^{224}$ See FED. R. CRIM. P. 6(e) (setting forth the general rule forbidding participants in the federal grand jury process from disclosing matters occurring before the grand jury).

${ }_{225}$ To be sure, the attorney may be better equipped than a nonlawyer to resist the pressures that can be brought to bear on her behind the closed doors of the grand jury room. Yet, as noted above, the attorney also has to deal with the very realistic fear that resisting the grand jury subpoena and litigating its validity will be costly in terms of her professional reputation and because of the diversion of time which such litigation involves. In addition, the attorney may fear that those who learn of the grand jury's interest in her may not know whether she was a prospective witness or target.

228 ABA Report II, supra note 218 , at 20 \& n.8 (quoting 34 Rec. A. B. City N.Y., 219, 224 (1979).

${ }^{227}$ See supra notes 170-82 and accompanying text (discussing Guidelines). 
dispute, however, on the most crucial point - that the usual "fishing expedition" power of the grand jury to cast a broad and speculative net is out of place when it comes to subpoenaing attorneys for information about their clients.

How are we to reconcile these interests in any given case? Currently, the law is unbalanced. There are very few enforceable rights that can be asserted to prevent a determined prosecutor from finding a basis for compelling evidence from the attorney. But a regime that grants prosecutors the virtually uninhibited power to destabilize or destroy the legal representation of an adversary, by the simple means of a well-aimed subpoena, is inconsistent with fundamental tenets of our legal system, the fairness of which depends, in large measure, on the zealous advocacy of counsel for the individual.

This Article, therefore, proposes four measures designed to restore a balance to the competing interests of the prosecution and grand jury on the one hand and the attorney-client relationship on the other. If adopted, these proposals would lead to results more consistent with the relevant policy considerations. ${ }^{228}$ The first two of these measures are primarily procedural reforms; the last two would add to existing privileges to cover some of the gaps through which prosecutors have reached in order to use the attorney as a witness against her client.

Our proposals are the following. First, every subpoena should be subject to judicial review to establish that it is needed. Second, judicial review should take place prior to issuance of an attorney subpoena in every case. Third, an attorney should be protected from compelled disclosure of any information that she acquired in the course of the representation and that would incriminate the client. Fourth, certain information that the attorney acquires as a result of the representation should be immune to compulsory process during the course of ongoing representation. ${ }^{229}$ The proposed privileges (i.e., proposals three and four) overlap both each other and existing protections. They could be implemented by judicial reconsideration of the limitations of existing privileges, or by means of common law development. ${ }^{230}$ Any of the four proposals could, of course, be implemented by rulemaking or

228 The four reforms have much in common with a model attorney subpoena rule, developed by the National Network for the Right to Counsel ("NNRC"), set out in Appendix B of this Article. These reforms could either function as part of a single rulemaking or legislative package, or stand alone and be individually justified by separate and overlapping sources of law. The authors of this Article are actively involved in the NNRC and participated in the drafting of the NNRC proposal.

${ }^{228}$ These last two proposals would be subject to exceptions in certain limited circumstances. See infra text accompanying notes 287-93, 300-03.

${ }^{230}$ See FED. R. Evid. 501. 
legislation.

\section{Judicial Review For Necessity}

There is little controversy as to whether there should be some determination of the need for evidence before an attorney subpoena is approved. Without such review, a prosecutor's demand for the most cumulative, unnecessary and easily found piece of evidence might result in the dismissal of a party's lawyer, or in other undesirable consequences. ${ }^{231}$ Indeed, even the Department of Justice Guidelines explicitly recognize that "the information sought [should be] reasonably needed for the successful completion of the investigation or prosecution," ${ }^{232}$ and that "[a]ll reasonable attempts to obtain the information from alternative sources shall have proved to be unsuccessful.".233 The Department contends, however, that the determination must be made unilaterally by the government and should not be committed in any way to judicial review.

Entrusting the attorney-client relationship to the prosecutor, an adversary with a strong interest in the outcome of the underlying controversy, is not a reliable method of safeguarding that relationship. Even in the best of circumstances, the prosecutor is unlikely to weigh the various interests in an unbiased manner. And, as noted above, for these and other reasons the Justice Department Guidelines have failed to effectively control the proliferation of attorney subpoenas. ${ }^{234}$

Opponents of judicial review argue that a required showing of need is contrary to (1) the traditional right of the prosecutor to choose what evidence to produce and (2) the power of the grand jury to obtain every person's evidence without any showing of cause. ${ }^{235}$ They point to the absence of broader protection under the attorney-client privilege as evidence of a policy not to impede the search for truth by blocking the grand jury's access to an attorney's testimony. Some suggest that judicial review would be too cumbersome and difficult to administer. ${ }^{236}$

However, the absence in current law of a general requirement of

${ }^{231}$ See supra notes 161-66 and accompanying text (discussing the problems associated with attorney subpoenas).

${ }^{232}$ GuIDELINES, supra note $170, \S 9-2.161(\mathrm{a})(\mathrm{F})(1)$.

${ }^{233}$ Id. § 9-2.161(a)(F)(3).

${ }^{234}$ See supra note 176 and accompanying text.

${ }^{235}$ See United States v. Klubock, 832 F.2d 649, 663 (1st Gir. 1987) (Campbell, C.J., dissenting) (arguing that requiring a showing of need before subpoenaing attorneys would be contrary to the traditional functioning of the grand jury).

${ }^{236}$ See In re Klein, 776 F.2d 628, 632 (7th Cir. 1985) (noting further that the question of "[h]ow much information is 'enough' is a matter for the judgment of the grand jurors and the prosecutors rather than the courts"). 
judicial review seems explicable more as a function of history and a lack of an occasion for its development than as a policy decision that the requirement should not be imposed. Until recently, attorney subpoenas were almost non-existent and there was no general government policy supporting their use. Indeed, what considered policy there was favored protection of the attorney-client relationship. For example, federal law has recognized that common law privileges designed to protect the attorney-client relationship should be enforced even in the grand jury, ${ }^{237}$ where the exclusionary rule does not apply ${ }^{238}$ and where other relationships and interests do not enjoy similar protection. ${ }^{239}$

Moreover, as a historical matter, the development of privilege protection has occurred primarily in response to new means of forcing disclosure of evidence. The attorney-client privilege first arose in direct response to the development of compulsory process for testimony. ${ }^{240}$ The need for the work-product privilege did not come about until the adoption of pre-trial discovery methods exposed the attorney's materials to compulsory disclosure. ${ }^{241}$ Now that a new need for protection of the attorney-client relationship has arisen, the fact that a proposal has not been adopted before should not be grounds for its rejection. Indeed, the Federal Rules of Evidence grant explicit power to the federal courts to develop new privileges where appropriate. ${ }^{242}$ Courts have exercised this power, at times in support of interests arguably much less weighty than the attorney-client relationship. ${ }^{243}$

Judicial screening for necessity is hardly unprecedented. ${ }^{244}$ It oc-

${ }^{237}$ See Upjohn Co. v. United States, 449 U.S. 383, 400-02 (1981).

${ }^{238}$ See United States v. Calandra, 414 U.S. 338, 348 (1974).

${ }^{239}$ See United States v. Nixon, 418 U.S. 683, 709 (1974) (rejecting claim of Presidential privilege by sitting President, but noting that "generally, an attorney ... may not be required to disclose what has been revealed in professional confidence"); Branzburg v. Hayes, 408 U.S. 665, 688 (1972) (rejecting proposed newsman's privilege but contrasting "those persons protected by a constitutional, common-law, or statutory privilege").

${ }_{240}$ See 8 J. Wigmore, supra note $49, \S 2290$.

243 See supra notes 76-78 and accompanying text.

242 See FFD. R. Evid. 501.

${ }^{243}$ E.g., United States v. Cintolo, 818 F.2d 980, 1002 (1st Cir. 1987) (finding a qualified privilege against government disclosure of "sensitive" electronic investigative techniques, because information disclosure "will enable criminals to frustrate future government surveillance and perhaps unduly jeopardize the security of ongoing investigations," (emphasis added)); United States v. Van Horn, 789 F.2d 1492, 1507-08 (11th Cir.) (holding that a privilege applies to the nature and location of electronic surveillance equipment but gives way if a need for the information is shown) cert. denied, 107 S.Ct. 190 (1986); United States v. Arthur Young \& Co., 677 F.2d 211, 219-21 (2d Cir. 1982) (finding an accountants' work-product privilege), affd in part, rev'd in part, 465 U.S. 805 (1984).

${ }_{244}$ See, e.g., United States v. Crockett, 506 F.2d 759, 760-61 (5th Cir.) ("As a general rule, a party's attorney should not be called as a witness unless his testimony is 
curs routinely, particularly in the grand jury context, whenever the subpoena calls for material subject to the qualified protection applicable to work product. ${ }^{245}$ It also forms part of the analysis employed by a court in considering, under Rule 17, whether an apparently burdensome or irregular subpoena is justified. ${ }^{246}$ Moreover, there is nothing about the process of criminal investigation that is so mysterious that a prosecutor could not explain the need for an item of evidence. Indeed, the Justice Department Guidelines require the prosecutor requesting the subpoena to offer just such an explanation. ${ }^{247}$ As a practical matter, if the prosecutor cannot demonstrate need, it is reasonable to presume either that it does not exist or that it does not outweigh countervailing interests.

Our proposal requires the government to carry the burden of making a clear and convincing demonstration to a judicial officer that the evidence sought is necessary at that time to the continued viability of a legitimate investigation or prosecution, and that all attempts to obtain the evidence from non-attorney sources have proved fruitless. An important requirement of the proposal is the showing of present need, which must be evaluated within the context of the countervailing interests of the attorney and client. Thus, if the subpoena would interfere with an ongoing representation and if the need for the evidence can be deferred until a later stage of the investigation or litigation, thereby minimizing disruption to the attorney-client relationship, approval of the subpoena should be denied. ${ }^{248}$ Another important element of our proposal is that the government must demonstrate cause to believe that the attorney possesses specific evidence needed by the prosecution. Mere speculation as to types of evidence which might aid the prosecutor if held by defense counsel should not justify compelling her

both necessary and unobtainable from other sources." (emphasis added) (citations omitted)), cert. denied, 423 U.S. 824 (1975).

${ }^{245}$ See Upjohn Co. v. United States, 449 U.S. 383, 397-402 (1981).

${ }^{248}$ See supra notes $112-15$ and accompanying text.

247 See Guidelines, supra note 170, § 9-2.161(a)(F).

248 For an example in the grand jury context, see In re Grand Jury Matters (Hodes and Gordon), 751 F.2d 13, 18-20 (1st Cir. 1984) (affirming district court's decision to quash subpoenas but preserving the "government's right to renew the subpoenas at a more suitable moment or upon a more substantial showing of immediate urgency and need").

Similarly, with respect to trial testimony, even if the government can show that the viability of a prosecution hinges upon the testimony sought, the subpoena should be denied if the testimony can be postponed and the delay would minimize disruption to the relationship. In practice, a trial can be postponed, or, if the evidence is admissible on less than all counts of an indictment, the counts that do not require the attorney's testimony could be severed and tried first so that the attorney's testimony would not become necessary until the remaining counts are ready for trial. 


\section{testimony.}

The practical effect of this proposal would be to shift the initial burden from the attorney (who, now, must challenge an objectionable subpoena) to the government (which, under our proposal, would have to justify subpoenaing the attorney). Of course, placing the initial burden upon the prosecutor's shoulders need not be dispositive of the outcome. As in the Rule 17 context, courts would consider the need for the subpoena in light of a number of relevant factors, such as unavailability of the information from alternative sources.

\section{Pre-Issuance Judicial Review}

We propose that judicial review take place prior to issuance of the subpoena, for two important reasons: first, such a procedure ensures that every case receives judicial review; second, and perhaps more important, the procedure will have a "self-regulatory" effect on potential prosecutorial overreaching. Current practice permits an unscrupulous prosecutor to take advantage of a frightened or compromised attorney by using an obviously invalid subpoena as a pretext for obtaining the disclosure of privileged information, since the prosecutor knows that the attorney will not challenge the subpoena and that the matter will be reviewed by neither court nor client. Advance judicial review would eliminate such sub rosa use of attorney subpoenas, and thus diminish the incentive for abuse.

The best procedure for judicial review would provide for a single adversary hearing, prior to issuance of the subpoena, with notice to both the attorney and her client. ${ }^{249}$ This procedure guarantees judicial review in all cases and it minimizes the risk of attorney disloyalty, Another method is that employed in the District of Massachusetts, ${ }^{250}$ where there is an ex parte proceeding to determine whether the subpoena should be served on the attorney, who can (if the subpoena is served) nevertheless file a motion to quash. Since preliminary review is ex parte, the focus is necessarily on the clearly abusive subpoena. The Massachusetts procedure thus guarantees some judicial review in all cases, but is a less effective screen for attorney disloyalty than a contested preliminary review.

The government argues that any pre-issuance review will cause the very type of unacceptable delay in grand jury investigations which concerned the Supreme Court when it condemned the notion of "mini-

249 See supra note 197 (noting Justice Department's approval of rule that would require showing that client had been notified of the attorney subpoena).

250 See supra notes 134-35 \& 184 and accompanying text (discussing PF 15). 
trials" for all grand jury subpoenas. ${ }^{251}$ In practice this need not be so. The Massachusetts ex parte procedure under PF 15 involves no more delay than that necessary to obtain a search warrant. PF 15 has now been in operation for over two years in Massachusetts, with no reported problems.

A pre-issuance adversary procedure would create some delay prior to issuance. Such a review, however, could supplant the motion to quash and could require both the client and witness to consolidate all grounds that could otherwise be raised at the motion to quash stage at this pre-issuance hearing. ${ }^{252}$ In this way, the only delay caused by the rule that is not already entailed by current practice would be that created by conducting hearings where attorneys do not now file motions to quash. This is a reasonable price to pay to ensure that attorneys adequately protect the rights of their clients, especially in light of the evidence that they do not invariably do so. ${ }^{283}$

\section{A "Non-Incrimination" Privilege}

Under our third proposed reform, the attorney would be protected at all times from compelled disclosure of information acquired in connection with representation of her client if that information would incriminate the client. This type of privilege is necessary in order to effectuate fully the well-recognized policies of encouraging persons to consult, retain, and confide in attorneys, ${ }^{254}$ to entrust counsel with plenary power to investigate their cases, ${ }^{255}$ and to encourage the attorney to make a thorough investigation as part of the duty of providing "effective" assistance. ${ }^{258}$ As noted above, currently recognized privileges are riddled with loopholes and qualifications; without this proposed new protection, a client who retains and confides in an attorney assumes the risk that information accumulated by the lawyer will be used to incriminate her, and a lawyer who conducts an investigation may find herself forced to disclose evidence ensuring her client's conviction. Indeed, without protection beyond that afforded by current law, continuation of present government subpoena practices may lead to significant changes in both client and attorney behavior. Without the type of "non-

251 See United States v. Dionisio, 410 U.S. 1, 16-17 (1973).

${ }^{252}$ The NNRC proposal does consolidate these two stages in one proceeding. See Appendix B $\$ \S 4-5$.

${ }^{283}$ See supra note 197 and accompanying text.

${ }^{254}$ See supra notes 200-14 and accompanying text.

255 See Hickman v. Taylor, 329 U.S. 495, 510-11 (1947).

${ }^{256}$ See Strickland v. Washington, 466 U.S. 668, 686 (1984) (citing McMann v. Richardson, 397 U.S. 759,771 n.14 (1970)). 
incrimination" privilege proposed here, a reasonable client would be extremely reluctant to share with her lawyer sensitive information or documents that could possibly fall outside the boundaries of any currently recognized privilege.

Similarly, forcing the attorney to provide evidence against her client creates severe impediments to the performance of her professional role. The cautious attorney would avoid acquiring any more information than she believed could be safely withheld from disclosure. This type of self-censorship by attorneys could result in the same sort of demoralization of lawyers and degradation of legal practice that the Supreme Court warned against in Hickman. Moreover, the attorney is ethically bound to maintain undivided loyalty to her client and to preserve the confidentiality of all client information. ${ }^{257}$ The contradiction between these obligations and the duty to produce evidence at the request of the government creates a dilemma for the practitioner who must encourage and maintain the client's continuing trust.

Furthermore, even when a client is not deterred from entrusting her attorney with information, turning the attorney into a government informant clearly violates our most fundamental notions of justice and fair play. This is especially apparent in criminal cases, where the need for representation arises from government action in the form of investigation or prosecution, and where the law sanctions, encourages, and in most cases, guarantees resort to counsel. Unfairness is particularly apparent if the government can reap the very information collected by the lawyer in the effort to defend the client against the government action.

In Doyle v. Ohio ${ }^{258}$ the Supreme Court found a due process violation in a similar sort of duplicity. There, the Court faced the issue of the admissibility at trial of a defendant's post-arrest silence, which the prosecution sought to use against the defendant for purposes of impeaching his credibility. The Court noted that the defendant had been given the warning required by Miranda $v$. Arizona, ${ }^{259}$ which informs detainees of their rights to remain silent and to demand counsel and which, therefore, implicitly encourages the detainee to believe that no penalty would be exacted for the exercise of those rights. Violation of that implicit assurance, the Court held, constituted a due process violation:

[W] hile it is true that the Miranda warnings contain no express assurance that silence will carry no penalty, such as- 
surance is implicit to any person who receives the warnings. In such circumstances, it would be fundamentally unfair and a deprivation of due process to allow the arrested person's silence to be used to impeach an explanation subsequently offered at trial. ${ }^{260}$

Similar reasoning applies when the government gives the individual a right to consult with counsel, then creates the need for the consultation by its own actions, and finally, exploits the individual's exercise of that right to undo her.

Subject to a few narrow exceptions, ${ }^{261}$ our proposal would elevate to the same privileged status as attorney-client communications all information acquired solely as a result of counsel's representation, if the information would tend to incriminate the client. ${ }^{262}$

A "non-incrimination" privilege serves several important purposes. First, the client would be assured that she can safely retain, consult with, and confide in her attorney without fear that her revelations and the information accumulated by the attorney might be used to incriminate her. Second, the attorney would be assured that she may safely

280 426 U.S. at 618. The Court has found constitutional violations in situations analogous to that in Doyle. See, e.g., Wainwright v. Greenfield, 106 S.Ct. 634, 641 (1986) (holding that a defendant's post-Miranda-warning silence may not be used to rebut an insanity defense); Estelle v. Smith, 451 U.S. 454 (1981) (holding that state could not use defendant's statements to court-appointed psychiatrist against him).

${ }^{261}$ See infra notes $287-93$ and accompanying text.

282 The proposed privilege would track the fifth amendment self-incrimination clause in two important respects. First, it would protect information that could harm the client only in a criminal proceeding. There are policy considerations that favor protection of the client from being harmed in other (non-criminal) settings by information gained by her own attorney in the course of representing her, and persuasive arguments can be made that the client should have similar protection in civil as well as criminal proceedings, particularly where the government is a party, such as in immigration, civil RICO, or tax cases. However, this Article does not address the question of whether the privilege proposed should be extended beyond the criminal context. The most compelling case for reform rests upon the unfairness of government action in criminal litigation and the greatest need for enhanced protection is found in that situation.

Second, the proposed privilege would utilize the familiar fifth amendment test for determining whether evidence tends to incriminate the client, that is, whether it furnishes "a link in the chain of evidence needed to prosecute." Hoffman v. United States, 341 U.S. 479, 486 (1951). Such a test is necessary because injury accrues to the attorney-client relationship by the attorney's disclosure of incriminating evidence regardless of whether the evidence provides a first or a "last link." See supra text accompanying note 63 (discussing "last link" exception to rule permitting disclosure of client identity and fee information). Under this test, the Government bears the burden of showing that it is "perfectly clear ... that the answer[s] cannot possibly have such tendency' to incriminate." Id. at 488 (citation omitted); see Malloy v. Hogan, 378 U.S. 1, 11-12 (1964). Unless the burden is placed on the government, the client often will have to relinquish the benefits of the privilege in order to demonstrate her right to claim it. 
investigate the matter for which she has been retained without fear that her efforts might later harm her client. Third, the non-incrimination privilege would have the effect of harmonizing counsel's ethical obligations with evidentiary rules, thus minimizing the dissonance and role conflict caused by current practices. Furthermore, the privilege as described here would not deprive the prosecution of information that would be available absent the existence of the attorney-client relationship. ${ }^{263}$ The privilege therefore would cause no net loss in the search for truth. ${ }^{264}$

In addition, the non-incrimination privilege as proposed would insulate precisely those categories of information that are incompletely protected under current privilege law: client identity, information relating to fees and expenses, and work product.

\section{a. Client Identity, Fees, and Expenses}

Client identity and fee and expense information have generally been considered unprotected by the attorney-client privilege. ${ }^{265}$ The traditional rationale for the attorney-client privilege - i.e., encouraging uninhibited client communication -- logically supports extending protection to the client's identity. On the one hand, of course, the information is normally obtained by means of client communication. Furthermore, confidentiality is as essential to promoting the consultation initially as it is to encouraging full disclosure during the course of the consultation. If clients had to risk incrimination in order to consult lawyers, they would hesitate to do so, perhaps until too late. ${ }^{266}$ A rule which encourages communication but penalizes consultation is paradoxical in principle and counterproductive in practice. Our proposal would permit the lawyer to withhold the name of a client who has consulted her for legal advice or legal services when the information might incriminate that client.

The protection of incriminating fee information from disclosure by the attorney is necessary to encourage individuals who need legal representation to seek it. This is so because, notwithstanding the develop-

${ }^{263}$ See infra text accompanying notes 289-92 (discussing exception for pre-existing material).

${ }^{264}$ See Developments in the Law, supra note 65, at 1507-08 \& n.43 (citing Upjohn Co. v. United States, 449 U.S. 383, 395 (1981)).

${ }^{265}$ See supra notes 56-65 and accompanying text.

${ }^{28 B}$ See In re Grand Jury Subpoena Duces Tecum (Shargel), 742 F.2d 61, 63 (2d Cir. 1984) ("[W]e would be less than candid not to concede that the lack of a privilege against disclosure of the fact of an attorney-client relationship may discourage some persons from seeking legal advice at all."). 
ment of the right to appointed counsel for indigent defendants, ${ }^{267}$ our criminal defense representation system is still primarily a private entrepreneurial system. Appointed counsel is not available before indictment, ${ }^{268}$ and, after formal charge, free counsel is available only to persons who meet legal standards of indigence. ${ }^{269}$ While an individual has a qualified right to retain counsel of choice, ${ }^{270}$ there is no comparable right to choose appointed counsel. ${ }^{271}$ Moreover, government subsidies to counsel are considerably below competitive rates, ${ }^{272}$ and fees and expenses are subject to approval of the court, ${ }^{273}$ which is itself influenced by overall budget constraints. In sum, money is an indispensable precondition to the exercise of the right to retain a chosen attorney, and, in most cases, the time and resources counsel is able to invest in the case is directly proportional to the amount of money available. ${ }^{274}$ These financial concerns are an especially important defense consideration in modern, complex criminal litigation, ${ }^{275}$ which has become a highly specialized endeavor requiring the use of experts and a well-staffed defense team. Preparation often entails pre-trial investigation of a wide range of conduct allegedly committed over the course of many years.

Given the inextricable relationship of money and counsel, it is not clear why information about fees and expenses is not accorded the same privileged status as client communications. The rationale for protecting attorney-client communications is the fear that without such protection

${ }^{267}$ Gideon v. Wainright, 372 U.S. 335, 344 (1963) ("The right of one charged with crime to counsel may not be deemed fundamental and essential to fair trials in some countries, but it is in ours.").

${ }^{288}$ See United States v. Gouveia, 467 U.S. 180, 188 (1984) ("The right to counsel does not attach until the initiation of adversary judicial [criminal] proceedings.").

${ }^{269}$ See Comment, Determining Eligibility for Public Defense: Constitutional Conflicts Posed by California Indigence Proceedings, 12 U.S.F. L. REv. 717, 720-21 (1978) (noting the requirement of indigence and the lack of consistency in federal statutory and judicial standards for determining it).

270 See supra note 98 and accompanying text (discussing sixth amendment right to counsel).

${ }_{271}$ See Tague, An Indigent's Right to the Attorney of His Choice, 27 STAN. L. REv. 73, 79 (1974) (observing that "[a]lmost unanimously, courts have held that the selection of counsel for an indigent is a matter within the sole discretion of the trial court"). See generally Annotation, Indigent Accused's Right to Choose Particular Counsel Appointed to Assist Him, 66 A.L.R.3d 996 (1975).

272 See Tague, supra note 271 , at 95-96.

${ }^{273}$ See id. at $97-98$.

274 See Morris v. Slappy, 461 U.S. 1, 23 (1983) (Brennan, J., concurring) (noting "the harsh reality that the quality of a criminal defendant's representation frequently may turn on his ability to retain the best counsel money can buy").

${ }^{276}$ See, e.g., United States v. Nichols, 654 F. Supp. 1541, 1559 n.23 (D. Utah 1987) ("When 28 individuals are charged with a long-term conspiracy and two are charged with a continuing criminal enterprise, the case is necessarily complex. Not all appointed counsel have the experience to defend such charges."), rev'd, (10th Gir. March 10, 1988) (LEXIS, Genfed library, Courts file). 
clients will not confide in lawyers. ${ }^{278}$ However, the practical effect of exposing fee arrangements is to inhibit payment of money for legal services. Clients will find it difficult to look to friends and supporters for help-the traditional means of marshalling resources for a criminal defense-so long as contributors might be enmeshed in a grand jury investigation or embarrassed by public exposure. ${ }^{277}$ The net result is that obtaining counsel of choice will become more difficult, if not impossible, for those who must rely on others for financial assistance.

Nevertheless, some courts treat the "benefactor" payment as an evil in itself, and therefore not worthy of privilege protection, ${ }^{278}$ out of concern that the benefactor may herself be a conspirator who will influence the legal representation of the beneficiary in order to conceal her own criminal liability. There is indeed a potential problem of conflict of interest when an attorney's fees are paid by someone other than the recipient of the legal services, ${ }^{279}$ but this risk must be weighed against the individual's interest in obtaining adequate resources for her defense. In general, our legal system has left it to the attorney and the informed client to strike this balance. Of course, if the attorney violates ethical rules governing conflicts of interest, such a violation should be remedied in the same manner as other violations of applicable ethical rules, that is, via bar discipline proceedings. There is nothing intrinsically improper, however, in an attorney's accepting a fee from a non-client, providing that the client consents after consultation and that there is no interference with the lawyer's independence, her professional judgment, or the attorney-client relationship. ${ }^{280}$ Nor is there a prohibition on multiple representation of clients if the lawyer believes that the representation of each client will be unimpaired and the clients consent after

276 See Fisher v. United States, 425 U.S. 391, 403 (1976) (stating that the "purpose of the privilege is to encourage clients to make full disclosure to their attorneys"). ${ }_{277} C f$. NAACP v. Alabama, 377 U.S. 288, 308 (1964) (stating that "compelled disclosure of the names of [NAACP members in Alabama] would entail 'the likelihood of a substantial restraint upon the exercise by [these] members of their'right to freedom of association." ").

${ }^{278}$ See, e.g., In re Grand Jury Subpoenas (Hirsch), 803 F.2d 493, 499 (9th Cir. 1986) ("The attorney-client relationship is not genuine where its only purpose is to gain confidentiality for the client or to use the lawyer as a mere conduit for the payment of money."); In re Grand Jury Subpoena Duces Tecum (Shargel), 742 F.2d 61, 64 (2d Cir. 1984) (holding that the attorney-client privilege does not shield benefactor payments).

279 See Model Rules of Professional Conduct Rule 1.8(f) (1987); Model Code of Professional ResPonsibility DR 5-107(A) (1980).

280 Model Rules of Professional Conduct Rule 1.8(f) (1987); Model Code of Professional Responsibility DR 5-107(A)(1) (1980); ABA Comm. on Ethics and Professional Responsibility, Formal Op. 320 (1968) (The "mere fact that the lawyer is actually paid by some entity other than the client does not affect [the attorney-client] relationship".). 
consultation. ${ }^{281}$

Moreover, the professional criminal organization will not, in the long run, be harmed by attorneys' testimony about fee arrangements: the sophisticated criminal will have little difficulty structuring financial transactions to insulate the lawyer from forbidden knowledge. On the contrary, the principal casualties of exposure will be ordinary citizens who, in the past, have relied on the generosity of friends, relatives, defense funds, and the like.

In short, there are compelling reasons for treating client identity and fee and expense information as privileged to the same extent as attorney-client communications. Nevertheless, we propose here only a more modest reform, which protects the attorney from being forced to testify about only those facts or communications that would incriminate her client.

\section{b. Work Product}

An additional type of information that needs increased protection is attorney work product. Currently, work product is protected by only a qualified privilege, and is subject to disclosure upon the government's showing of adequate need. We submit, however, that in a criminal matter, absent extraordinary circumstances of the kind discussed below, ${ }^{282}$ no showing of need should ever be deemed adequate if the information sought was lawfully acquired ${ }^{283}$ by the lawyer as a result of a present, or a substantially related, representation and would incriminate the client if disclosed. Protection of such information is particularly necessary in the criminal defense setting because, as the Supreme Court has noted, the role of the work-product doctrine in "assuring the proper functioning of the criminal justice system is even more vital" than in the civil litigation context. ${ }^{284}$ The criminal defense lawyer, for example, generally obtains confidential information about the client or the case which the government cannot, or does not, obtain on its own. It would be especially unfair for the government to gain access to incriminating evidence solely because the defendant, in the face of a government investigation or prosecution, exercised her constitutional right to

281 Model Rules of Professional Conduct Rule 1.7(b) (1987); Model Code of Professional Responsibility DR 5-105(C) (1980).

${ }^{282}$ See infra notes 287-303 and accompanying text (discussing limited situations in which the non-incrimination privilege should give way).

${ }^{283}$ Our proposal would allow an exception to the privilege in certain circumstances when the lawyer's prior services were used in the commission of a crime. See infra text accompanying note 293.

${ }^{284}$ United States v. Nobles, 422 U.S. 225, 238 (1975). 
counsel. ${ }^{285}$ The criminal defense has no burden of turning incriminatory information over to the government comparable to the duty of the prosecution to disclose exculpatory information to the defense. ${ }^{286}$ Thus, the government's "need" for work product accumulated as part of a criminal defense arises in a context entirely different from that of civil litigation. It is arguable, therefore, that whenever the information is collected as part of a criminal representation, it should be protected by an unqualified privilege.

Once again, however, the "non-incrimination" privilege we propose here is more limited: it would require that the work-product privilege be absolute only when the work product from an ongoing, or substantially related, matter would incriminate the client.

\section{c. Exceptions}

The "non-incrimination" privilege urged here should give way to the government's demand for evidence in some limited situations namely, where the government has a strong need and no legitimate interest of the client is threatened.

(i) "Use Immunity"

If the attorney's testimony cannot possibly harm the client in any criminal proceeding, then the concerns on which the privilege is premised are satisfied and the privilege proposed here should give way. ${ }^{\mathbf{2 8 7}}$ The government can remove the threat of harm to the client simply by guaranteeing that the information will not be used against the client. Thus a "non-incrimination" privilege would give way whenever the government makes a binding commitment of "use plus fruits" immunity, under which the evidence could not be used by the government either directly or indirectly against the client. ${ }^{288}$

\section{(ii) Pre-existing Materials}

Occasionally, the attorney's investigation turns up certain unique items which (1) existed prior to the inception of the representation, (2) were thus in no way generated by the representation, and (3) are in no

${ }^{285}$ See supra notes 258-60 and accompanying text.

${ }^{286}$ See United States v. Wade, 388 U.S. 218, 258-59 (1967) (White, J., dissenting); Brady v. Maryland, 373 U.S. 83, 87 (1962)

${ }_{287}$ See supra note 9 and accompanying text; text accompanying note 29.

${ }^{288}$ Cf. Kastigar v. United States, 406 U.S. 441, $443-47$ (1972) (testimony may be compelled from an unwilling witness over a claim of privilege against self-incrimination by a grant of use and derivative use immunity). 
other way privileged. Examples are instrumentalities and fruits of criminal conduct, such as a murder weapon ${ }^{289}$ or stolen bank notes. ${ }^{290}$ No privilege excuses the lawyer from producing such materials; were it otherwise, the defense relationship could be used as a "sanctuary" to insulate admissible evidence from production. Our proposal would recognize a similar exception. ${ }^{201}$ Additionally, even with respect to nonunique pre-existing materials, the government should be permitted to obtain the evidence from the lawyer when it is obvious that the materials have been transferred to the attorney for the sole purpose of concealment.

The logic of the privilege mandates, however, that the client not be harmed by the fact per se that the item was obtained by the prosecution from the client's lawyer. Consistent with the current majority rule, all reference to the attorney as source must be avoided. ${ }^{292}$

\section{(iii) Griminal Conduct in the Representation}

If the evidence sought was acquired by the attorney when the client was using her services in the commission of a crime, the client should not be able to insulate herself from incrimination solely by virtue of her relationship with the attorney. We would permit the attorney's testimony or work product to be elicited upon a satisfactory showing that the information related to the attorney's services and those services were utilized in the commission of a crime. The exception, however, should be narrowly construed, in order to prevent it, like the crime/fraud exception, from becoming the rule. ${ }^{293}$ In particular, the government should have to make a strong showing of illegality, subject to rebuttal, based upon reliable evidence independent of that sought from the attorney.

\section{A "Current Representation" Privilege}

Our fourth proposal is to create a privilege that would immunize from production via attorney subpoena all information relating to a le-

${ }^{280}$ E.g., State v. Green, 493 So.2d 1178, 1182-83 (La. 1986); Commonwealth v. Stenbach, 356 Pa. Super. 5, 16-23, 514 A.2d 114, 119-23 (1986), .

${ }_{200}$ E.g. In re Ryder, 263 F. Supp. 360, 365-66 (E.D. Va.), affd, 381 F.2d 713, 714 (4th Cir. 1967).

${ }_{201}$ See generally Lefstein, Incriminating Physical Evidence, the Attorney's Dilemma, and the Need for Rules, 64 N.C.L. REv. 897, 901-10 (1986) (reviewing cases involving defense attorneys' obligation to turn over physical evidence).

${ }_{282}$ See State v. Olwell, 64 Wash. 2d 828, 834, 394 P.2d 681, 684 (1964); Lefstein, supra note 291, at 902 .

${ }_{293}$ See supra notes 66-75 and accompanying text. 
gal representation during the course of that representation. This rule is needed to prevent undue disruption of the attorney-client relationship during an ongoing representation and to prevent unnecessary disqualification of chosen counsel. The proposed rule provides that a lawyer may not be compelled to testify if (1) she currently represents the client in a criminal matter, ${ }^{294}$ (2) the information sought was acquired as a result of this or a substantially related representation, and (3) compelling the testimony would create a substantial risk of disqualification of the attorney or disruption of the attorney-client relationship in the current representation.

Unlike the "non-incrimination" privilege, a "current representation" privilege attempts to shield the attorney-client relationship from intrusion and interference during a particular time period, that is, during the representation itself. By contrast, the "non-incrimination" privilege would extend indefinitely but cover a somewhat narrower range of information -- namely, those statements and documents which would incriminate the client. ${ }^{295}$

The privilege should extend to material obtained as a result of legal representation in substantially related matters. ${ }^{296}$ Otherwise, the privilege would prove to be ineffectual in any case involving multiple proceedings. For example, suppose an attorney represents an individual through grand jury investigation and then on the ensuing indictment; after indictment, the government opens a "second" grand jury investigation into whether obstruction of justice was committed during the "previous" investigation. ${ }^{287}$ The proposed current representation privi-

294 As with the non-incrimination privilege, see supra note 262 and accompanying text, there are strong policy considerations that favor extension of a current representation privilege to civil proceedings. Yet we limit the scope of the proposal in this Article to criminal litigation, including grand jury proceedings, where the client's interests are the weightiest and the need for reform is most acute.

${ }^{293}$ In practice, the privileges substantially overlap. However, there are several areas in which the protection offered by the two would be incongruent: the "non-incrimination" privilege would leave open to discovery (a) statements made by the client to the attorney which are non-privileged (perhaps because they were made in public) or non-incriminating (such as non-incriminating client identity and fee information); (b) non-incriminating attorney work product; and (c) any other non-incriminating documents or information acquired in the course of representing the client.

${ }^{298}$ The "substantial relationship" test seems well-suited to determining whether two representations are sufficiently interrelated to justify a presumption that compelling information acquired from one will interfere with counsel's representation in the other. The test is derived from that used to decide disqualification motions in conflict of interest cases, in order to determine whether courts will employ a presumption that an attorney who opposes a former client possesses confidential information obtained from the client, which can be used to that client's detriment. See, e.g., Consolidated Theaters, Inc. v. Warner Bros. Circuit Management, 216 F.2d 920, 922 (2d Cir. 1954); ModeL. Rules of Professional Conduct Rule 1.9(a) (1987).

${ }^{297}$ See Case No. 4, supra note 4 and accompanying text. 
lege would insulate the attorney from subpoena through the "second" representation.

Under our proposal, for both ethical and practical reasons, the privilege would be triggered by a "substantial risk" of disruption or disqualification. First, under the ethical rules, the attorney must withdraw as soon as possible if there is a risk that she will be called as a witness. ${ }^{298}$ Even if the government did not plan to move for her disqualification, the attorney should not continue that representation. Second, as a practical matter, the purpose of a current representation privilege would be defeated if the rule could not be invoked at the earliest moment when there was a reasonable chance of disruption of the attorney-client relationship. Surely, to wait until such disruption has already begun could fatally undermine the representation and the relationship of trust on which it depends. ${ }^{299}$

The "current representation" privilege would be subject to exceptions similar to those proposed in connection with the "non-incrimination" privilege, above. First, the privilege could be overcome by a grant of "use immunity" for the client with respect to future use, in any criminal proceeding, of the information sought. ${ }^{300}$ If the evidence could neither be introduced against the, client in any criminal proceeding, nor be used to further a criminal investigation of the client, then the risk that the lawyer would have to withdraw because of a conflict of interest or because of her role as a witness would dissipate. Second, the privilege would not apply to pre-existing unique materials and to materials transferred to the attorney solely for purposes of concealment, although all such evidence, if obtained by the prosecution, must be offered at trial without any reference to the attorney as source. ${ }^{301}$ Third, the privilege would also be lost if the prosecutor can establish by clear and convincing evidence that the representation is a sham, undertaken solely for the purpose of rendering the attorney incompetent as a witness. Finally, the protection would be lost upon a proper showing ${ }^{302}$ that the current representation was used to further a crime. ${ }^{303}$

\section{ConClusion}

The Justice Department's current extensive practice of subpoena-

${ }^{298}$ See supra note 24 and accompanying text.

299 See supra note 30 and accompanying text.

300 See supra note 288 and accompanying text.

${ }^{301}$ See State v. Olwell, 64 Wash. 2d 828, 834, 394 P.2d 681, 684 (1964); supra text accompanying note 293 .

${ }^{302}$ See supra notes 66-75 and accompanying text.

${ }^{303}$ See supra note 293 and accompanying text. 
ing attorneys to produce client information represents a sharp break with the traditions and settled expectations on which our legal system is based. The costs of this practice have ranged from disruption to total destruction of the attorney-client relationship, with additional injuries to the bar generally and the criminal defense bar in particular.

Current legal protections do not safeguard the attorney-client relationship adequately. Because of significant gaps in the coverage of existing attorney-client and work-product privileges, some discoverable information in an attorney's possession can usually be obtained by a prosecutor determined to make that attorney a witness. Faced with the generally unwelcome prospect of compelling attorneys to testify against their clients, some courts have attempted to close gaps in the area of privilege, and other courts have used their supervisory power to regulate the use of attorney subpoenas. Overall, however, new safeguards have not kept pace with the changing investigative and prosecutorial strategies of the government and the growing need to protect the attorney-client relationship.

This Article proposes four reforms to restore the balance between the individual's right to counsel and the government's need for evidence. These proposals include procedures and standards for judicial review that would restrict the government's attempts to obtain client information from the client's attorney, especially when the information would incriminate the client or when the attorney is still representing the client. If these procedures were employed in, for example, each of the four hypothetical cases presented earlier ${ }^{304}$ the government would be unable to obtain the information it requested, absent an extraordinary showing. ${ }^{305}$

Our proposals would, in general, invert the current situation in

so4 See supra notes 1-4 and accompanying text.

${ }^{305}$ In Case Nos. 1 and 2, the client identity and fee information would be absolutely privileged under the non-incrimination privilege and under the current representation privilege so long as the attorney continued to represent the clients, unless the government undertook to guarantee "use immunity" for the testimony. If use immunity were granted, the information could be obtained, upon a showing of need, to the extent that it is not privileged by the attorney-client or work-product privileges.

In Case Nos. 3 and 4, the information is covered by the non-incrimination privilege. Further, the information sought by the government was obtained by the lawyer in a substantially related representation and thus, in each case, the lawyer cannot be subpoenaed while she continues to represent the client in the pending indictment. However, both of these privileges could be overcome if the government makes a convincing showing that a crime was committed (on the basis of evidence other than testimony or documents from the attorney and subject to defendant's rebuttal). Even under this circumstance, the government must make a compelling showing of present need. If the need for the evidence could be deferred until after the attorney completes her representation of the defendant on the pending indictment, the subpoena would be disallowed. 
which the attorney's ability to avoid testifying against her client is the exception. Our proposals are not inflexible, however, and they provide the government discovery opportunities when the client is insulated from harm, when unique, pre-existing materials are sought, when the privileges are abused by sham relationships or transactions, or when the representation has furthered the commission of a criminal offense. In turn, when a client is not currently represented and the information would not incriminate the client, the government could obtain otherwise non-privileged information from the client's attorney by making a showing of need.

Adoption of these proposals would restore greater reliability and predictability to the confidentiality of attorney-client communications, including information (such as client identity and fee information) which is often treated by the courts as lying outside the scope of such protection. If these four proposals become law, attorneys will be able to give their clients broader assurance that the information acquired in the course of their representation will remain confidential. Unfortunately, under present law and current government practices, the attorney cannot yet give her client such assurances.

While our proposals might be considered far-reaching, they are certainly less so than the policy of regularly using attorneys as witnesses against their clients. It is that policy which represents a bold innovation in our legal system - one which the measures proposed here seek to regulate. 


\section{APPENDICES}

\section{Appendix A}

\section{U.S. Department of Justice}

Attorney-Subpoena Guidelines

Executive Office for the United States Attorneys, Department of Justice, United States Attorneys' Manual. $\S 9-2.161$ (a) (1985)

Policy With Regard to the Issuance of Grand Jury or Trial Subpoenas to Attorneys for Information Relating to the Representation of Clients.

Because of the potential effects upon an attorney-client relationship that may result from the issuance of a subpoena to an attorney for information relating to the representation of a client, it is important that the Department exercise close control over the issuance of such subpoenas. Therefore, the following guidelines shall be adhered to by all members of the Department in any matter involving a grand jury or trial subpoena:

A. In determining whether to issue a subpoena in any matter to an attorney for information relating to the representation of a client, the approach must be to strike the proper balance between the public's interest in the fair administration of justice and effective law enforcement and individual's right to the effective assistance of counsel.

B. All reasonable attempts shall be made to obtain information from alternative sources before issuing a subpoena to an attorney for information relating to the representation of a client, unless such efforts would compromise a criminal investigation or prosecution or would impair the ability to obtain such information from an attorney if such attempts prove unsuccessful.

G. All reasonable attempts shall be made to voluntarily obtain information from an attorney before issuing a subpoena to an attorney for information relating to the representation of a client, unless such efforts would compromise a criminal investigation or prosecution or would impair the ability to subpoena such information from the attorney if such attempts prove unsuccessful.

D. No subpoena may be issued in any matter to an attorney for information relating to the representation of a client without the express authorization of the Assistant Attorney General of the Griminal Division.

E. In approving the issuance of a subpoena in any matter to an 
attorney for information relating to the representation of a client, the Assistant Attorney General of the Griminal Division shall apply the following principles:

(1) In a criminal investigation or prosecution, there must be reasonable grounds to believe that a crime has been or is being committed and that the information sought is reasonably needed for the successful completion of the investigation or prosecution. The subpoena must not be used to obtain peripheral or speculative information;

(2) In a civil case, there must be reasonable grounds to believe that the information sought is reasonably necessary to the successful completion of the litigation.

(3) All reasonable attempts to obtain the information from alternative sources shall have proved to be unsuccessful;

(4) The reasonable need for the information must outweigh the potential adverse effects upon the attorney-client relationship. In particular, the need for the information must outweigh the risk that the attorney will be disqualified from representation of the client as a result of having to testify against the client;

(5) Subpoenas shall be narrowly drawn and directed at material information regarding a limited subject matter and shall cover a reasonably limited period of time; and

(6) The information sought shall not be protected by a valid claim of privilege.

These guidelines on the issuance of grand jury or trial subpoenas to attorneys for information relating to the representation of clients are set forth solely for the purpose of internal Department of Justice guidance. They are not intended to, do not, and may not be relied upon to create any rights, substantive or procedural, enforceable at law by any party in any matter, civil or criminal, nor do they place any limitations on otherwise lawful investigative or litigative prerogatives of the Department of Justice. 


\author{
Appendix B \\ National Network for the Right to Counsel: \\ Attorney-Subpoena Proposal
}

\title{
LIMITATIONS ON LAWYER-CLIENT SUBPOENAS
}

Sec. 1. Definitions. As used in this rule:

a. A "client" is a person, public officer, or corporation, association, or other organization or entity, public or private, who is rendered professional legal service by a lawyer, or who consults a lawyer with a view to obtaining professional legal service from the lawyer.

b. A "lawyer" is a person authorized or reasonably believed by the client to be authorized to practice law in any state or territory of the United States.

c. A "lawyer's representative" is a person employed to assist the lawyer in the rendition of professional legal service.

d. A "lawyer-client subpoena" is a subpoena, or judicial or administrative order, issued to a lawyer or to a lawyer's representative, requiring the lawyer or the lawyer's representative to provide testimony, documents or tangible objects concerning a former or current client.

Sec. 2. No lawyer-client subpoena shall be issued in any proceeding in which the government is a party, except upon a judicial determination made after an opportunity for an evidentiary hearing, held in accordance with due process, at which the client, as well as the proposed recipient of the subpoena, has the right to participate, and at which the government must prove by clear and convincing evidence that each of the terms and conditions set forth in section 3 of this rule are met.

Sec. 3. In order for a lawyer-client subpoena to be issued, all of the following terms and conditions must be met:

a. The lawyer-client subpoena lists with particularity the specific testimony, document(s) or tangible object(s) sought to be provided;

b. There is probable cause to believe that each specific item of testimony or tangible object sought to be provided is related to or is evidence of past or present criminal activity;

c. Each specific item of testimony or document or tangible object sought to be provided is necessary to the continued viability of a legitimate government investigation or prosecution, and all alternative non- 
attorney sources for the item have been exhausted;

d. No specific item of testimony or document or tangible object sought to be provided is protected from disclosure by any statutory, common law or constitutional privilege of the lawyer or client; and

e. If the lawyer is currently representing the client in connection with an ongoing government investigation or a judicial or administrative proceeding in which the government is a party, the lawyer-client subpoena does not seek:

i. testimony concerning information relating to, or learned during the course of, professional legal service rendered to, or legal consultation with, the client;

ii. testimony or document(s) or tangible object(s) relating to fees and/or expenses paid to the lawyer or to the lawyer's representative by, or on behalf of, the client for professional legal service or consultation.

This section does not prevent the issuance of a subpoena for document(s) transferred to a lawyer for a purpose other than seeking legal advice from the lawyer.

Sec. 4. In the event that the government satisfies its burden of proving all of the terms and conditions set forth in section 3 , the lawyer-client subpoena nonetheless shall not be issued if a judicial determination is made that some other ground to quash the subpoena exists, provided that such a determination shall be made in accordance with the same procedures and standards applicable on a motion to quash a subpoena.

Sec. 5. The grant or denial of a lawyer-client subpoena pursuant to this rule shall be appealable as a final order, provided that a judicial determination made pursuant to section 4 shall be appealable only to the extent that it would be appealable if made on a motion to quash a subpoena. 
Appendix C

\section{AMERICAN BAR ASSOCIATION RESOLUTION}

(Adopted by ABA House of Delegates in February, 1986)

BE IT RESOLVED, That a prosecuting attorney shall not subpoena nor cause a subpoena to be issued to an attorney to a grand jury without prior judicial approval in circumstances where the prosecutor seeks to compel the attorney/witness to provide evidence concerning a person who is represented by the attorney/witness; and

BE IT FURTHER RESOLVED, That prior judicial approval shall be withheld unless the court, in an ex parte hearing, finds:

1. the information sought is not protected from disclosure by the attorney-client privilege or the work product doctrine;

2. the evidence sought is relevant to an investigation within the jurisdiction of the grand jury;

3. the purpose of the subpoena is not primarily to harass the attorney/witness or his or her client; and

4. there is no other feasible alternative to obtain the information sought.

BE IT FURTHER RESOLVED, That the ex parte hearing seeking judicial approval shall be conducted with consideration for the need for the secrecy of grand jury proceedings. The hearing shall be conducted by a judge of a court of general criminal jurisdiction, and, wherever feasible, by the judge supervising the grand jury in question; and

BE IT FURTHER RESOLVED, That no affirmative finding in the ex parte proceeding shall have any evidentiary value in any subsequent adversary proceeding to determine the validity or enforcement of the subpoena; and

BE IT FURTHER RESOLVED, That the American Bar Association urges that these principles be implemented by state and federal authorities through appropriate means such as rules of court, statutes, and case law. 
Appendix D

\section{AMERICAN BAR ASSOCIATION RESOLUTION}

(Adopted by ABA House of Delegates in February, 1988)

BE IT RESOLVED, That a prosecuting attorney shall not subpoena nor cause a subpoena to be issued to an attorney without prior judicial approval after an opportunity for an adversarial proceeding in circumstances where evidence obtained as a result of the attorney-client relationship concerning a person who is or was represented by the attorney; and

BE IT FURTHER RESOLVED, That prior judicial approval shall be withheld unless the court finds, on reasonable notice to the attorney and the client:

1. the information sought is not protected from disclosure by any applicable privilege;

2. the evidence sought is essential to the successful completion of an ongoing investigation or prosecution and is not merely peripheral, cumulative or speculative;

3. the subpoena lists the information sought with particularity, is directed at information regarding a limited subject matter and a reasonably limited period of time and gives reasonable and timely notice;

4. the purpose of the subpoena is not to harass the attorney or his or her client; and

5. the prosecutor has unsuccessfully made all reasonable attempts to obtain the information sought from non-attorney sources and there is no other feasible alternative to obtain the information.

BE IT FURTHER RESOLVED, That at the hearing, the prosecutor seeking to subpoena information as defined above, must submit to the appropriate court an affidavit making a particularized showing of the facts establishing all of the requirements specified above. The affidavit shall be disclosed to the attorney and the client. However, upon a special showing of compelling need, the affidavit may be maintained as an ex parte affidavit until such time as the need for secrecy is no longer compelling; and

BE IT FURTHER RESOLVED, That any hearing seeking judicial approval for a grand jury subpoena shall be conducted with consideration for the need for secrecy; and

BE IT FURTHER RESOLVED, That the American Bar Association urges that these principles be implemented by state and federal 
authorities through appropriate means such as rules of court, statutes, and case law. 